\title{
The Aluminum Conundrum in Hawaiian Shield-Building Lavas: An Argument for a Deep, Garnet-Bearing, Mantle Source.
}

\author{
J. Michael Rhodes ${ }^{1}$ \\ ${ }^{1}$ Department of Geosciences, University of Massachusetts, Amherst, MA 01003 USA (email \\ jmrhodes@geo.umass.edu).
}

\begin{abstract}
In contrast with other major elements (e.g. $\mathrm{SiO}_{2}, \mathrm{CaO}, \mathrm{TiO}_{2}$ ), isotopic ratios (e.g. Sr, $\mathrm{Nd}, \mathrm{Pb}$ ), and some trace element ratios (e.g. $\mathrm{Zr} / \mathrm{Nb}, \mathrm{Zr} / \mathrm{Y}, \mathrm{La} / \mathrm{Nb}$ ), the $\mathrm{Al}_{2} \mathrm{O}_{3}$ content of Hawaiian shield lavas, at a given $\mathrm{MgO}$ content, is remarkably uniform within and between volcanoes. The overall range at 10 percent $\mathrm{MgO}$ is about $0.8 \%$ from Loihi (12.1\%) to Koolau (12.9\%). There is substantial overlap between the "Loa" and "Kea" trend volcanoes, but the regression data for "Loa" trend volcanoes are slightly higher $(0.2 \%)$ in $\mathrm{Al}_{2} \mathrm{O}_{3}$ than "Kea" trend volcanoes. Post-shield lavas, from both "Kea" and "Loa" trends are higher in $\mathrm{Al}_{2} \mathrm{O}_{3}$ at a given $\mathrm{MgO}$ content than corresponding shield lavas. These observations are completely at odds with what we think we know about melt production in a heterogeneous, thermally zoned, mantle plume. Peridotite melting models and experiments, at varying pressures and temperatures, result in melts with significantly different $\mathrm{Al}_{2} \mathrm{O}_{3}$ contents at a given $\mathrm{MgO}$ content. The almost constant $\mathrm{Al}_{2} \mathrm{O}_{3}$ at a given $\mathrm{MgO}$ content is analogous to the almost constant normalized $\mathrm{Yb}$ abundances in Hawaiian tholeiites. Both require melting in the presence of a garnet residue. The aluminum conundrum can be explained if Hawaiian shield lavas result from melting garnet peridotite at depths corresponding to around $120 \mathrm{~km}$. However, this explanation is at odds with the variable, but relatively high $\mathrm{SiO}_{2}$ contents of most of these lavas, which imply melt production at relatively shallow depths corresponding to less than $90 \mathrm{~km}$. This paradox can be resolved if low $\mathrm{SiO}_{2}$ parental magmas derived from garnet peridotite react with a depleted harzburgite residue from prior melting as the magma ascends through the upper regions of the plume.
\end{abstract}

\section{Introduction}

The compositions of basaltic magmas erupted from Hawaiian volcanoes are widely interpreted to be a consequence of melting and magma production as individual volcanoes are transported by the northwest-moving Pacific plate over a stationary, thermally-zoned and compositionallyheterogeneous mantle plume [e.g. Watson and Mackenzie, 1991; Frey and Rhodes, 1993; Ribe and Christensen, 1999; Farnetani and Hofmann, 2010]. The most compelling evidence for this inference is found in the compositional differences between shield-stage and post- and pre-shield stage volcanism [Stearns and Macdonald, 1946; Macdonald et al., 1983; Moore and Clague, 
34 1992]. Shield- stage lavas are tholeiitic, whereas post- and pre-shield stage lavas are often alkalic,

35 or characterized by transitional tholeiites with lower $\mathrm{SiO}_{2}$ and higher alkali and incompatible

36 element content than shield-stage lavas. These differences are thought to be indicative of lower

37 degrees of magma production at the cooler margins of the plume, an inference supported not only

38 by the presence of alkalic and low $\mathrm{SiO}_{2}$ lavas with high incompatible element abundances, but

39 also by a greater preponderance of evolved lavas in the post-shield stage [e.g. Frey et al., 1991;

40 Feigenson et al., 1983], accompanied by almost an order of magnitude reduction in lava

41 accumulation rates [Sharpe and Renne, 2005].

42 Therefore, as a volcano traverses the thermally-zoned and compositionally-heterogeneous mantle

43 plume, we should expect to find significant differences in: melt production between volcanoes;

44 melt production over time at individual volcanoes; the depth of melt segregation, within and

45 between volcanoes; and the proportion of source components, within and between volcanoes. To

46 a large extent these expectations are realized, given the difficulties in sampling the $\sim 100 \mathrm{ka}$

47 magmatic histories of young Hawaiian volcanoes [e.g. DePaolo and Stolper, 1996; Quane et al.,

48 2000; Stolper et al., 2009; Rhodes, 2015]. There are significant differences between individual

49 volcanoes and, sometimes, during the growth of an individual volcano, in major elements, trace

50 elements and isotopic ratios [e.g. Wright, 1971; Staudigal et al., 1984; Garcia et al., 1989; Rhodes

51 et al, 1989; Lassiter et al., 1996; Frey et al., 2001; Frey and Rhodes, 1993; Rhodes and Vollinger,

52 2004; Stolper et al., 2004; Abouchami et al., 2005; Weis et al, 2011; Jackson et al., 2012].

53 The differences in major element composition of lavas erupted during the shield-building stage of

54 individual Hawaiian volcanoes has long been recognized [e.g. Powers, 1955; Wright, 1971; 
55 Rhodes et al., 1989; Garcia et al., 1989; Moore and Clague, 1992; Frey and Rhodes, 1993]. In

56 particular, volcanoes along the westerly "Loa" and easterly "Kea" trends of Jackson et al. (1972)

57 differ significantly from one another. For example, at a given $\mathrm{MgO}$ content, "Kea" trend lavas

58 tend to be lower in $\mathrm{SiO}_{2}$, and higher in $\mathrm{CaO}, \mathrm{TiO}_{2}, \mathrm{Na}_{2} \mathrm{O}$ and $\mathrm{K}_{2} \mathrm{O}$ than "Loa" trend lavas. They

59 also tend to be higher in highly incompatible trace element abundances. See figures 3 to 6 in

60 Jackson et al. [2012] for a detailed summary of major element and isotopic differences between

61 Hawaiian volcanoes and the "Loa" and "Kea" trends. Lower abundances of MgO-normalized

$62 \mathrm{TiO}_{2}$ and other incompatible major and trace elements are generally attributed to a greater extent

63 of melting needed to produce the "Loa" trend magmas compared to the Kea trend magmas [e.g.

64 Hofmann and Farnetani, 2013]. In contrast, normalized $\mathrm{SiO}_{2}$ is pressure-dependant, relating to

65 the depth of melt segregation from a peridotite source [e.g. Carmichael et al, 1970; Albarède,

66 1992; Lee et al, 2009], and also to the extent of peridotite melting [e.g. Kushiro, 1996; Walter,

67 1998; Longhi, 2002]. On the other hand, the apparent correlation of normalized $\mathrm{SiO}_{2}$ abundances

68 with isotopic ratios has been used as an argument for varying amounts of a subducted oceanic

69 crustal eclogite/pyroxenite component, mixed with a peridotite component, in the plume source

70 of Hawaiian volcanoes [e.g. Hauri, 1996; Takahashi and Nakajima, 2002; Sobolev et al., 2005;

71 Jackson et al., 2012]. Herzberg [2006] takes this even further, arguing that only high $\mathrm{CaO}-$ low

$72 \mathrm{SiO}_{2}$ lavas from Loihi and Mauna Kea are derived from peridotite melting, all others are produced

73 by melting of an olivine-free eclogite/pyroxenite source.

74 What is surprising is that, despite the well-documented variations in $\mathrm{MgO}$ normalized $\mathrm{SiO}_{2}, \mathrm{CaO}$

75 and $\mathrm{TiO}_{2}$, the $\mathrm{MgO}$ normalized abundances of $\mathrm{Al}_{2} \mathrm{O}_{3}$ are remarkably uniform in Hawaiian shield-

76 building lavas, with very little difference between individual volcanoes, or between "Kea” and 
77 "Loa" trend volcanoes. This presents a conundrum, because examination of the results of

78 peridotite melting experiments leads one to expect that the $\mathrm{Al}_{2} \mathrm{O}_{3}$ content of a melt will be

79 sensitive to the extent of melting as well as to the depth at which the melt segregates from its

80 residue [e.g. Kushiro, 1996; Walter, 1998; Longhi, 2002; Salters et al., 2002]. Additionally,

81 assuming much of the heterogeneity inferred for the Hawaiian plume results from mixtures of

82 peridotite and subducted oceanic crustal components, one might anticipate considerable variation

83 in $\mathrm{Al}_{2} \mathrm{O}_{3}$ content in Hawaiian shield-building lavas. Indeed, Sobolev et al., [2005, Fig. 4] use the

$84 \mathrm{Al}_{2} \mathrm{O}_{3}$ content of inferred primary magmas to estimate the proportions of melt derived from a

85 pyroxenitic component in the Hawaiian plume. In this paper, I will document the extraordinary

86 uniformity of $\mathrm{Al}_{2} \mathrm{O}_{3}$ among Hawaiian shield-building lavas from volcanoes along both the "Loa"

87 and "Kea" trends, arguing that the only plausible reason for this uniformity is the presence of

88 substantial garnet in the source peridotite. This implies that these magmas were derived by

89 melting of garnet peridotite in the Hawaiian plume at depths greater than $90 \mathrm{~km}$ and most

90 probably closer to about $120 \mathrm{~km}$.

\section{2. Analytical Methods}

92 About $200-600 \mathrm{~g}$ of sample were crushed by hand in a high-carbon steel percussion mortar. The

93 resulting gravel-sized fragments were washed in tap water, followed by washing in an ultrasonic

94 bath with de-ionized water. About 100 - $200 \mathrm{~g}$ was further crushed to about 200 mesh size in a

95 Spex tungsten carbide (WC) shatterbox. Aliquants of this powder were analyzed by X-ray

96 fluorescence analysis (XRF). The major elements were measured on a fused La-bearing lithium

97 borate glass disc using modifications of the method of Norrish and Hutton [1969], the principle

98 difference being that the samples are first ignited at $1000-1040{ }^{\circ} \mathrm{C}$ for several hours in order to 
99 oxidize iron to $\mathrm{Fe}^{3+}$ and remove volatiles. They are then fused in an electric furnace at $\sim 1020{ }^{\circ} \mathrm{C}$

100 and pressed into glass discs. All oxides were measured in duplicate on a Siemens MRS-400

101 simultaneous spectrometer. Analyses that did not give summations between 99.4 and 100.3

102 percent were discarded and repeated. Estimates of the precision and accuracy of these data are

103 given by Rhodes [1996] and Rhodes and Vollinger [2004]. Of specific relevance to this paper the

104 precision for $\mathrm{Al}_{2} \mathrm{O}_{3}$ and $\mathrm{MgO}$ are 0.06 and 0.03 weight percent (2 sigma) respectively.

105 Because the differences in $\mathrm{Al}_{2} \mathrm{O}_{3}$ content of lavas from different Hawaiian volcanoes are small, I

106 have restricted the study to data generated by X-ray Fluorescence Spectroscopy (XRF) in my

107 laboratory at the University of Massachusetts, in order to minimize the possible effects of inter-

108 laboratory bias. The data have been archived in the EarthChem Library and are available for

109 download from www.earthchem.org/library/rhodes

\section{3. The $\mathrm{Al}_{2} \mathrm{O}_{3}$ Content of Hawaiian Shield-Stage Lavas}

111 Plots of major element compositions against $\mathrm{MgO}$ in Hawaiian shield-stage tholeiites show that at

112 around $7 \% \mathrm{MgO}$ there are two contrasting trends. In one trend, compositions range in $\mathrm{MgO}$

113 content between 6.8 and $35.0 \mathrm{wt}$. \%. This is controlled primarily through olivine fractionation

114 and accumulation, and plots along strong linear trends, the so-called "olivine-control trends", that

115 converge towards olivine compositions [e.g. Powers, 1955; Murata and Richter, 1966; Wright,

116 1971; Wilkinson and Hensel, 1988; Clague et al, 1995; Rhodes, 1995]. The other trend has

117 cooled and crystallized beyond olivine control. These lavas are more evolved, with $\mathrm{MgO}<6.8 \%$,

118 and are multiply-saturated, crystallizing clinopyroxene and plagioclase in addition to olivine and

119 sometimes orthopyroxene. Most analyses of Hawaiian tholeiitic glass fall into this category [e.g.

120 Garcia et al., 1989; Moore and Clague, 1992; Clague et al, 1995; Stolper et al., 2004]. A few 
121 highly evolved lavas exhibit compositional evidence for the crystallization of magnetite/ilmenite 122 and even apatite.

123 In order to evaluate the $\mathrm{Al}_{2} \mathrm{O}_{3}$ content of lavas from Hawaiian tholeiitic shield-stage volcanoes I

124 have restricted the study to lavas along olivine-control trends with $\mathrm{MgO}>6.8 \%$. This avoids the

125 effects on $\mathrm{Al}_{2} \mathrm{O}_{3}$ relative to $\mathrm{MgO}$ of plagioclase and clinopyroxene crystallization in evolved or

126 mixed magmas. I have also confined the study to relatively unaltered lavas indicated by low Loss

127 on Ignition $\left(\mathrm{LOI}<1 \%\right.$ ) and with $\mathrm{K}_{2} \mathrm{O} / \mathrm{P}_{2} \mathrm{O}_{5}>1.0$ [e.g Lipman et al., 1991; Frey et al., 1994]. This

128 study is based on over 1,800 major element analyses of Hawaiian shied-building tholeites that lie

129 on olivine-control trends. Most are from Mauna Loa, Mauna Kea and Kilauea.

\section{$130 \quad 3.1 \mathrm{Al}_{2} \mathrm{O}_{3}$ in "Loa Trend" Volcanoes}

131 3.1.1 Mauna Loa - the recorded magmatic history for Mauna Loa spans around 600 - $700 \mathrm{ka}$.

132 Sub-aerial samples account for about $120 \mathrm{ka}$ of this history and include data for historical lavas

133 (1843-1984 [Rhodes, 1989; Rhodes and Hart, 1995]), prehistoric ${ }^{14} \mathrm{C}$-dated lavas (0.2-36 ka

134 [Lockwood, 1995; Trusdell and Lockwood, in press]) and samples from the Hawaii Scientific

135 Drilling Project (0.3-120 ka [Rhodes, 1996; Sharp et al., 1996; Rhodes and Vollinger, 2004;

136 Sharp and Renne, 2005]. Submarine lavas from Mauna Loa's southwest rift zone, and from the

$1371600 \mathrm{~m}$ high Kahuka landslide scarp that dissects the submarine southwest rift zone [Garcia et 138 al., 1995b], have ${ }^{40} \mathrm{Ar} /{ }^{39} \mathrm{Ar}$ ages from 59 to around 600 - $700 \mathrm{ka}$ [Jicha et al., 2012]. Recently,

139 Rhodes [2015] utilized the relationship between water depth and ${ }^{40} \mathrm{Ar} /{ }^{39} \mathrm{Ar}$ ages to infer ages for

140 other submarine Mauna Loa lavas. Despite this long magmatic history ( 600 - $700 \mathrm{ka})$, Fig. 1a

141 shows that $\mathrm{Al}_{2} \mathrm{O}_{3}$ vs $\mathrm{MgO}$ plots for these samples are extremely coherent and that there is no

142 difference in $\mathrm{Al}_{2} \mathrm{O}_{3}$ at a given $\mathrm{MgO}$ content, either with age or between sub-aerial and submarine 
143 lavas. Table 1 provides the regression data for these trends, confirming that there is no significant

144 difference between them. Note that the enigmatic alkaline submarine Mauna Loa lavas erupted

145 from submarine radial vents near Kealakekua Bay [Wanless et al., 2006] are excluded from Fig.

146 1a because they plot off the olivine control trends.

147 3.1.2 Loihi - the data for Loihi come from samples discussed in Garcia et al. [1995; 1998]. All

148 are tholeiitic and, with the exception of five samples that erupted in 1996, are of uncertain age.

149 Although Loihi is isotopically a "Loa trend" volcano, and widely considered an end-member

150 plume- source component [e.g. Staudigal et al., 1984; Garcia et al. 1995; Abouchami et al.,

151 2005; Weis et al., 2011], the major element compositions of its lavas are low in $\mathrm{SiO}_{2}$ and high in

$152 \mathrm{CaO}$ and $\mathrm{TiO}_{2}$, similar to "Kea trend" lavas. Also, at a given $\mathrm{MgO}$ content, the $\mathrm{Al}_{2} \mathrm{O}_{3}$ content of

153 Loihi lavas are slightly lower than other "Loa trend" lavas, closer to "Kea trend" lavas (Table 1;

$154 \quad$ Fig. 1b].

155 3.1.3 Hualalai - analyses of the Hualalai shield-stage tholeiites were made on sub-marine lavas

156 sampled by Garcia et al., [1989]. Compositionally, they are indistinguishable from Mauna Loa

157 lavas, with comparable $\mathrm{Al}_{2} \mathrm{O}_{3}$ at a given $\mathrm{MgO}$ (Fig. 1c, Table 1). On the other hand, post-shield

158 Hualalai lavas are higher in $\mathrm{Al}_{2} \mathrm{O}_{3}$ at a given $\mathrm{MgO}$ than corresponding shield-stage lavas (Fig. 1c

159 Table 1). This is consistent with post-shield Mauna Kea and Kohala lavas that also tend to be

160 higher in $\mathrm{Al}_{2} \mathrm{O}_{3}$ at a given $\mathrm{MgO}$ than their shield-stage counterparts.

161 3.1.4 Mahukona - the data for Mahukona, the smallest, somewhat enigmatic, Hawaiian shield

162 volcano are from Garcia et al. [2012]. They include both normal tholeiites and samples that are

163 transitional to alkali basalt, probably post-shield. The tholeiites have $\mathrm{Al}_{2} \mathrm{O}_{3}$ values at a given

$164 \mathrm{MgO}$ content that overlap with shield-stage tholeiites of Mauna Loa and Hualalai, whereas the 
165 transitional basalts have higher $\mathrm{Al}_{2} \mathrm{O}_{3}$ values relative to $\mathrm{MgO}$ content, similar to post-shield lavas 166 from Hualalai (Table 1, Fig. 1e).

167 3.1.5 Koolau - the data for Koolau come from Frey et al. [1994] and from the Koolau Scientific 168 Drilling Project [Haskin and Garcia, 2004] and include samples from both the Makapuu- and the 169 underlying Kahila-stages. The Makapuu-stage lavas of Koolau have generated a great deal of 170 interest because of their high $\mathrm{SiO}_{2}$ content relative to other Hawaiian tholeites and their end171 member isotopic compositions with low $\mathrm{Pb}$ and $\mathrm{Nd}$ isotopic ratios and correspondingly higher $\mathrm{Sr}$ 172 ratios [e.g Frey et al., 1994; Fekiacova et al., 2007; Weis et al., 2011], characteristics widely 173 inferred to indicate recycled oceanic crustal components, including sediments, in the plume source 174 [e.g. Hauri, 1996; Blichert-Toft et al., 1999; Takahashi and Nakamura, 2002: Huang and Frey, 175 2005: Fekiacova et al., 2007]. In contrast, the Kahila-stage lavas are compositionally and 176 isotopically similar to those of Mauna Loa [Haskin and Garcia, 2004; Huang and Frey, 2005; 177 Fekiacova et al., 2007 ]. Many of the Makapuu-stage lavas were rejected for this study because 178 they were altered $\left(\mathrm{K}_{2} \mathrm{O} / \mathrm{P}_{2} \mathrm{O}_{5}<1.0\right)$, or had fractionated beyond olivine-control $(\mathrm{MgO}<6.8 \%)$.

179 Both Makapuu- and Kahila-stage lavas have $\mathrm{Al}_{2} \mathrm{O}_{3}$ values at a given $\mathrm{MgO}$ content that overlap 180 with those of Mauna Loa and Hualalai, but tend to be slightly on the high side (Table 1, Fig. 1d).

181 3.1.6. Kahoolawe - the data are from Huang et al. [2005]. Samples from this volcano have high $182 \mathrm{SiO}_{2}$ contents similar to Makapuu-stage Koolau lavas and broadly similar isotopic characteristics 183 [Huang et al.,2005]. $\mathrm{Al}_{2} \mathrm{O}_{3}$ values at a given $\mathrm{MgO}$ are also similar to, and overlapping, the 184 Maakapuu-stage Koolau lavas (Table 1, Fig. 1d).

\section{$185 \quad 3.2 \mathrm{Al}_{2} \mathbf{O}_{3}$ in "Kea Trend" Volcanoes}


3.2.1 Kilauea - the data for Kilauea span at least 24 ka of its eruptive history and include historical lavas (1790 - 2008) [Pietruska and Garcia, 1999; Garcia et al, 2000; Marske et al., 2007], prehistoric ${ }^{14} \mathrm{C}$-dated lavas that are mostly < 5 ka [Holcomb, 1987; Rhodes et al., 1989; Moore and Morris, 1996], lavas from the Hilina Pali over 22 ka in age [Chen et al.,1996] and submarine pillow lavas from the Puna Ridge [Clague et al., 1995]. On the basis of the thickness

191 of palagonite rims on glass, Clague et al. [1995] speculate that the range in age of these

192 submarine flows is around $0.7-24 \mathrm{ka}$. In spite of the age range of over $24 \mathrm{ka}$, and the fact that 193 isotopic data indicate different proportions of source components during this period [e.g. Chen et 194 al., 1996; Pietruszka and Garcia, 1999; Abouchanii et al., 2005; Marske et al., 2007; Weis et al., 195 2011] that fluctuate within decades [Pietruszka and Garcia, 1999], there are no discernible differences in $\mathrm{Al}_{2} \mathrm{O}_{3}$ at a given $\mathrm{MgO}$ content (Fig. 2a). Table 1 gives the regression data for these

197 trends. There is a small difference in slope for the Puu Oo lavas, probably because the trends for 198 these lavas are largely determined by olivine fractionation, whereas the others involve both olivine 199 fractionation and accumulation. Nonetheless, the $\mathrm{Al}_{2} \mathrm{O}_{3}$ at a given $\mathrm{MgO}$ content overlaps with 200 those of other Kilauea lavas (Table 1).

201 3.2.2 Mauna Kea - data used here for Mauna Kea comes primarily from the Hawaii Scientific 202 Drilling Project (HSDP) [Stolper et al., 1996; Rhodes, 1996; Rhodes and Vollinger, 2004; Stolper 203 et al., 2009; Rhodes et al., 2012]. Shield-stage lavas from Mauna Kea range in age from the 204 transition to post-shield lavas at around $330 \mathrm{ka}$ to extrapolated ages of around $690 \mathrm{ka}$ at the bottom 205 of the hole [e.g. Sharp et al., 1996; Sharp and Renne, 2005; Rhodes et al., 2012]. During this $206 \sim 360$ ka interval Mauna Kea erupted four distinct, and inter-layered, magma types [e.g. Rhodes and 207 Vollinger, 2004; Stolper et al., 2004]. High-silica tholeiites (the type-1 lavas of Rhodes and 
Vollinger, 2004) are the most abundant, erupted throughout the entire $\sim 360$ ka stratigraphic column, and including sub-aerial flows, submarine pillow lavas and hyaloclastites. In the upper part of the column (353-1740 mbsl) there are low-silica tholeiites (the type-2 lavas of Rhodes and

211 Vollinger, 2004), inter-layered with the high-silica tholeiites. They occur as sub-aerial flows and

212 sub-marine pillow lavas. Both magma types have similar incompatible element abundances and 213 ratios, but both include lavas with different $\mathrm{Pb}$ isotopic ratios (the low-8 and mid-8 $\mathrm{Pb}$ isotopic 214 groups of Eisele et al., 2003). This indicates that the difference in $\mathrm{SiO}_{2}$ between these two lava 215 types is largely dependant on the depth of melt extraction and not on the extent of melting or the 216 source composition [Rhodes et al., 2012]. Between 1765 and 1810 mbsl there are enigmatic and 217 controversial high - $\mathrm{CaO}$ hyaloclastites [Stolper et al., 2004]. These are low- silica tholeiites, but 218 have higher incompatible element abundances and are distinct from other shield-stage lavas. 219 Herzberg [2006] argues, on the basis of their high $\mathrm{CaO}$ content, that they are the only Hawaiian 220 magmas derived from a peridotite source, whereas Rhodes et al. [2012] infer that they are low221 degree melts (similar to post-shield magmas) produced during a brief waning phase of Mauna 222 Kea's shield-stage volcanism. In the lower part of the hole, below $2467 \mathrm{mbsl}$, pillow lavas and 223 intrusive dikes of an additional low-silica tholeiite (the type-3 lavas of Rhodes and Vollinger, 224 2004) are inter-layered with the high-silica tholeites. Geochemically and isotopically these are 225 very similar to low-silica tholeiites from Loihi [Garcia et al., 1995a; Eisele et al., 2003; Rhodes 226 and Vollinger, 2004; Stolper et al., 2004].

227 Despite the long $\sim 360$ ka magmatic record and geochemical and isotopic diversity indicative of 228 different proportions of at least four source components, different depths of melt segregation and 229 melt production, there are only small differences in $\mathrm{Al}_{2} \mathrm{O}_{3}$ at a given $\mathrm{MgO}$ content (Fig. 2b). There 
230 is essentially no difference between the low- and high- silica (types-1 and 2) lavas or the high $\mathrm{CaO}$

231 lavas. The low-silica, Loihi-like, lavas type-3) are slightly higher in $\mathrm{Al}_{2} \mathrm{O}_{3}$ at a given $\mathrm{MgO}$ content.

232 Table 1 provides the regression data for these trends, showing that there is no significant

233 difference between them. Post-shield lavas are slightly higher in $\mathrm{Al}_{2} \mathrm{O}_{3}$ at a given $\mathrm{MgO}$, similar to

234 post-shield lavas from Hualalai and other volcanoes (Fig. 2d, Table 1).

235 3.2.3 Kohala - analyses of the Kohala shield-stage tholeiites were made on sub-marine lavas

236 sampled by Garcia et al., [1989] and sub-aerial samples studied by Feigenson et al. [1983]. Only

237 a few sub-aerial samples are considered because most are altered $\left(\mathrm{K}_{2} \mathrm{O} / \mathrm{P}_{2} \mathrm{O}_{5}>1.0\right)$ or evolved

238 with $\mathrm{MgO}<6.8 \%$. Nonetheless, the nine samples available plot well within the range for other

239 "Kea Trend" volcanoes (Fig. 2c; Table 1) with similar $\mathrm{Al}_{2} \mathrm{O}_{3}$ content at a given $\mathrm{MgO}$. The few

240 post-shield lavas surviving the screening have higher $\mathrm{Al}_{2} \mathrm{O}_{3}$ values $(\sim 1 \%)$ with $\mathrm{MgO}$, similar to

241 Mauna Kea post-shield lavas, and post-shield lavas of the other volcanoes.

242 3.2.4 Loa vs Kea Trends - Table 1 provides the regression data for each of the volcanoes

243 discussed above, and the estimated $\mathrm{Al}_{2} \mathrm{O}_{3}$ contents at 10 and 16 weight percent $\mathrm{MgO}$. There is

244 considerable overlap both within and between volcanoes. The maximum difference in $\mathrm{Al}_{2} \mathrm{O}_{3}$,

245 between the lower Loihi trend and that of the upper Makapuu-stage of Koolau is only about 0.8

246 weight percent. Figure 3 compares $\mathrm{Al}_{2} \mathrm{O}_{3}$ content versus $\mathrm{MgO}$ for the combined "Kea" and "Loa"

247 trends. Again, there is considerable overlap between the two trends, but the regression through the

248 Loa trend data is slightly higher in $\mathrm{Al}_{2} \mathrm{O}_{3}$, by about 0.2 weight percent, than that through the "Kea"

249 trend data. This difference, although small, is statistically significant. It may not, however,

250 necessarily reflect a higher $\mathrm{Al}_{2} \mathrm{O}_{3}$ content in "Loa" trend lavas, but may be, in part, an artifact of

251 olivine accumulation. The two trends are numerically dominated by data from Mauna Loa and 
252 Mauna Kea (Table 1). At high MgO Mauna Loa picrites contain olivines that are slightly more

253 forsteritic (modal and maximum values of $\mathrm{Fo}_{90}$ and $\mathrm{Fo}_{91.3}$ respectively) than those of Mauna Kea

254 (modal and maximum values of $\mathrm{Fo}_{88}$ and $\mathrm{Fo}_{90.5}$ respectively) [Garcia et al., 1995; Baker et al 1996;

255 Garcia, 1996; Putirka et al., 2011; Rhodes, 2015]. This small difference in Fo content of

256 accumulative olivines could contribute to a small apparent difference in $\mathrm{Al}_{2} \mathrm{O}_{3}$ content of the two 257 trends.

\section{4. Discussion}

259 Current thinking about the nature of the Hawaiian plume recognizes that it is probably thermally 260 and compositionally zoned [e.g. Watson and McKenzie, 1991; DePaolo and Stolper, 1996; Ribe 261 and Christiansen, 1999; Farnetani and Hofmann, 2010], with well-documented chemical and 262 isotopic heterogeneity [e.g. Hofmann amd White, 1982; Staudigal et al., 1984; Lassiter and Hauri, 263 1996; Blichert-Toft et al., 1999; Abouchami et al., 2000; Huang and Frey, 2005; Weis et al., 264 2011]. These heterogeneities are thought to related to varying contributions of recycled oceanic 265 crust [e.g. Hofmann amd White, 1982; Lassiter et al., 1996; Hofmann, 1997; Blichert-Toft et al., 266 1999]. They may, or may not, reflect source components derived from lithological differences 267 between peridotite and recycled oceanic crustal eclogite/pyroxenite [e.g. Hauri, 1996; Takahashi 268 and Nakajima, 2002; Sobolev et al., 2005; Herzberg,2006; Jackson et al., 2012]. Whatever the 269 cause, as a volcano traverses the mantle plume, we might expect to find evidence for: differences 270 in melt production over time at individual volcanoes; differences in melt production between 271 volcanoes; differences in the depth of melt segregation within and between volcanoes; and 272 differences in the proportion of source components, within and between volcanoes. 
Experimental melting of peridotite and basalt that is in equilibrium with a peridotite assemblage can produce a wide range in major element melt compositions from alkalic basalts to picrites, with compositions controlled both by the extent of melting and the pressure (depth) of melt segregation [e.g. Kushiro, 1996; Walter, 1998; Longhi, 2002; Salters et al., 2002]. Additionally, it has been proposed that Hawaiian magmas may be produced by melting of lithologically distinct mixtures of peridotite and re-cycled oceanic crustal components (eclogite/pyroxenite) [e.g. Hauri, 1996; Takahashi and Nakajima, 2002; Sobolev et al., 2005; Herzberg,2006; Jackson et al., 2012]. In this case we should also expect differences in major element compositions, as well as in trace element 281 abundances and isotopic signatures. These expectations are reflected in differences in most major 282 elements between volcanoes, especially those from the "Loa" and "Kea" trends [e.g. Wright, 1971; 283 Garcia et al., 1989; Rhodes et al., 1989; Moore and Clague, 1992;Frey and Rhodes, 1993; Frey et 284 al., 1994; Hauri, 1996; Jackson et al., 2012] and sometimes within the long-time record of an 285 individual volcano [e.g. Quane et al., 2000; Haskin and Garcia, 2004; Rhodes and Vollinger, 286 2004; Stolper et al., 2004]. However, although peridotite melting experiments indicate that $\mathrm{Al}_{2} \mathrm{O}_{3}$ 287 should also vary with the extent and depth of melting, I have shown above (Table 1; Figs, 1 - 3) 288 that the $\mathrm{Al}_{2} \mathrm{O}_{3}$ content of Hawaiian shield-building tholeiites is almost constant at a given $\mathrm{MgO}$. 289 What is the reason for this conundrum, and what does it tell us about the production and source of 290 these magmas? The following sections explore these questions.

\section{$291 \quad 4.1$ Harzburgite Melting}

292 Experimental melting of peridotites and basalts indicates that the high- $\mathrm{SiO}_{2} \mathrm{Hawaiian}$ magmas 293 from both the "Loa" and "Kea" trend volcanoes, which are volumetrically predominant during the 294 shield-building stage, are produced at low pressures $(<2.2 \mathrm{GPa})$, corresponding to depths of less 
than $70 \mathrm{~km}$ and that they are in equilibrium with a harzburgite residue. They are not in equilibrium

296 with garnet lherzolite at any pressure [e.g. Eggins, 1992; Wagner and Grove, 1997; Herzberg and

297 O'Hara, 2002; Maaloe, 2004]. Figure 4a uses the Herzberg and O'Hara (2002) paramaterization

298 of harzburgite melting to explore the effects of both pressure and extent of melting on $\mathrm{MgO}$ -

$299 \mathrm{Al}_{2} \mathrm{O}_{3}$ relationships in Hawaiian tholeiites. In this figure the melt fraction at pressures ranging

300 from 1 to $5 \mathrm{GPa}$ is between 0.2 to 0.5 . The $\mathrm{Al}_{2} \mathrm{O}_{3}$ and $\mathrm{MgO}$ contents of these melts are influenced

301 by both depth of melt production and the extent of melting. Both result in a decrease in $\mathrm{Al}_{2} \mathrm{O}_{3}$ in

302 the melt with increasing $\mathrm{MgO}$ indicating that $\mathrm{Al}_{2} \mathrm{O}_{3}$ is incompatible during melting. On the other

303 hand, at a given $\mathrm{MgO}$ concentration, melts generated at higher pressures tend to have slightly

304 higher $\mathrm{Al}_{2} \mathrm{O}_{3}$ than those produced at a lower pressure. From these relationships, we should expect

305 to see a significant range of compositions, including $\mathrm{Al}_{2} \mathrm{O}_{3}$, for magmas produced by differing

306 degrees of melt extraction and at different depths within the plume, or from ascending polybaric

307 melt columns in different parts of the plume. This is inconsistent with the data for $\mathrm{Al}_{2} \mathrm{O}_{3}$ presented

308 earlier.

$309 \quad 4.2$ Lherzolite Melting

310 I have utilized data from the melting experiments of Walter [1998] and those of Longhi [2002],

311 reported in Salters et al., [2002], to evaluate the effects of the depth and extent of melting on the

$312 \mathrm{Al}_{2} \mathrm{O}_{3}$ and $\mathrm{MgO}$ contents of melts from lherzolite (Fig. 4b). The experiments of Walter [1998]

313 were on the West Kettle River spinel peridotite between 3 and $7 \mathrm{GPa}$. The composition of this

314 peridotite is thought to be close to that of primitive mantle or pyrolite [Walter, 1998]. In contrast,

315 the experiments of Salters et al., [2002] were on synthetic picritic melts in equilibrium with a

316 peridotite assemblage between 1 and $3.5 \mathrm{GPa}$. Despite the differences in approach the results are 
very consistent (see also Putirka et al., 2011, Fig. 6c). There is an overall trend of decreasing

$318 \mathrm{Al}_{2} \mathrm{O}_{3}$ and increasing $\mathrm{MgO}$ with depth of melting between 2 and $7 \mathrm{GPa}$ (Fig. 4b). This trend is

319 similar to, and overlaps with, the trend shown previously for harzburgite melting (Fig. 4a). At

320 pressures below $3 \mathrm{GPa}$, where garnet is absent, the results are similar to those inferred for

321 harzburgite melting (Fig. 4a), and both depth and extent of melting result in a significant decrease

322 in $\mathrm{Al}_{2} \mathrm{O}_{3}$ with increasing $\mathrm{MgO}$.

323 Melts generated at pressures above $3 \mathrm{GPa}$, where garnet is stable, behave quite differently. An

324 overall marked decrease in $\mathrm{Al}_{2} \mathrm{O}_{3}$ and increase in $\mathrm{MgO}$ with increasing pressure prevails but, in

325 contrast, increase in melt production at a given pressure results in a slight increase in $\mathrm{Al}_{2} \mathrm{O}_{3}$ with

326 increasing $\mathrm{MgO}$ (Fig. 4b). This indicates that garnet, the main source of $\mathrm{Al}_{2} \mathrm{O}_{3}$ in the melt, is a

327 residual phase at these pressures.. The overall trend of experimental melts overlaps the

328 compositional trend for Hawaiian shield-building tholeiites at around 18 to 22 weight percent $\mathrm{MgO}$

329 at pressures between 4 and $6 \mathrm{GPa}$. Putirka et al. [2011, Fig. 6] show a similar overlap for $\mathrm{Al}_{2} \mathrm{O}_{3}$

330 and other oxides at these pressures. That this is close to the inferred $\mathrm{MgO}$ content of parental

331 Hawaiian tholeitic magmas, based on olivine - melt relationships, is surely no coincidence [e.g.

332 Wilkinson and Hensel, 1988; Rhodes, 1995; Norman and Garcia, 1999; Rhodes and Vollinger,

333 2004; Putirka, 2005; Putirka et al., 2011]. Additionally, because these melting trends are only

334 slightly positive (Fig. 4b), there is little increase in $\mathrm{Al}_{2} \mathrm{O}_{3}$ irrespective of the range in melting.

335 There is also a tendency for the slopes of the melting trends to increase with increasing pressure,

336 implying a greater garnet influence with depth. This provides a ready explanation for the almost

337 constant $\mathrm{Al}_{2} \mathrm{O}_{3}$ at a fixed $\mathrm{MgO}$ for all Hawaiian shield-building tholeites.

$338 \quad 4.3$ Melting Models 
339 Here, I further explore the consequences of melting of garnet-free and garnet-bearing peridotites

340 on the $\mathrm{MgO}$ and $\mathrm{Al}_{2} \mathrm{O}_{3}$ contents of basaltic melts, in order to broadly simulate the experimental

341 melting trends of Walter [1998] and Salters et al. [2002]. This is shown in Figure 4c using the

342 simple non-modal batch melting equation of Shaw [1970].

$$
\mathrm{C}_{\mathrm{o}}=\mathrm{C}_{\mathrm{s}} *\left[1 /\left(\mathrm{D}_{\mathrm{o}}+\mathrm{F}\left(1-\mathrm{P}_{\mathrm{o}}\right)\right]\right.
$$

$344 \mathrm{C}_{\mathrm{o}}$ is the concentration in the melt, $\mathrm{C}_{\mathrm{s}}$ is the concentration in the source, $\mathrm{F}$ is the melt fraction, $\mathrm{D}_{\mathrm{o}}$ is 345 the bulk distribution coefficient $\left(\mathrm{D}_{\mathrm{o}}=\mathrm{F}_{\mathrm{o} 1} * \mathrm{Kd}_{\mathrm{ol}}+\mathrm{F}_{\mathrm{opx}} * \mathrm{Kd}_{\mathrm{opx}}+\mathrm{F}_{\mathrm{cpx}} * \mathrm{Kd}_{\mathrm{cpx}}+\mathrm{F}_{\mathrm{ga}} * \mathrm{Kd}_{\mathrm{ga}}\right)$ based on 346 the modal mineralogy of the source and the distribution coefficients $(\mathrm{Kd})$ between minerals and 347 melt. $\mathrm{P}_{\mathrm{o}}$ is based on the fraction of minerals $(\mathrm{P})$ entering the melt and the distribution coefficients $348(\mathrm{Kd})$ between minerals and melt $\left(\mathrm{P}_{\mathrm{o}}=\mathrm{P}_{\mathrm{ol}} * \mathrm{Kd}_{\mathrm{ol}}+\mathrm{P}_{\mathrm{opx}} * \mathrm{Kd}_{\mathrm{opx}}+\mathrm{P}_{\mathrm{cpx}} * \mathrm{Kd}_{\mathrm{cpx}}+\mathrm{P}_{\mathrm{ga}} * \mathrm{Kd}_{\mathrm{ga}}\right)$.

349 The distribution coefficients for $\mathrm{Al}_{2} \mathrm{O}_{3}$ and $\mathrm{MgO}$ between mineral and melt are obtained from the 350 experimental data of Walter [1998] and Salters et al. [2002]. Considering the different 351 experimental approaches, they are encouragingly coherent . Most correlate strongly with both 352 temperature and pressure (Appendix A)

353 The $\mathrm{MgO}$ and $\mathrm{Al}_{2} \mathrm{O}_{3}$ content of the starting material (the West Kettle River spinel peridotite (KR 354 4003)) in these experiments, are 37.3 and 4.26 weight percent, respectively. The mineralogical 355 modal proportions at different pressures are from Walter [1998, Table 8, Fig. 3]. It is important to 356 note that at $3 \mathrm{GPa}$ the melt-free peridotite contains only about 2 percent garnet, but the garnet 357 content increases with increasing pressure up to around 17 percent at $7 \mathrm{GPa}$. Accompanying this 358 increase there is an increase in the $\mathrm{Kd}$ for $\mathrm{Al}_{2} \mathrm{O}_{3}$ in garnet (Appendix $\mathrm{A}$ ). $\mathrm{D}_{\mathrm{o}}$ is calculated from 359 these Kd's and the modal proportions and $\mathrm{P}_{\mathrm{o}}$ from the Kd's and the melt reactions of Walter [1998, 
360 Table 9] at 3 and 7 GPa. Additionally, in order to simulate the experimental melt trends I have

361 empirically estimated $\mathrm{D}_{\mathrm{o}}$ and $\mathrm{P}_{\mathrm{o}}$ from compositions of successive experimental melts at a given $\mathrm{P}$.

362 The results of these calculations are shown in Figure 4c, showing melting curves at various

363 pressures. Melting is shown between 1 and 30 percent in increments of 10 percent. Broadly

364 speaking, these melting curves follow the experimental melting trends shown in Figure 4b. At 3

$365 \mathrm{GPa}$ the calculated melting curve conforms with the experimental trend and $\mathrm{Al}_{2} \mathrm{O}_{3}$ is

366 incompatible, decreasing with increased melting and $\mathrm{MgO}$. This is because the 2 percent garnet in

367 the starting peridotite is rapidly consumed by melting. Note also that melting from 10 to 20

368 percent results in a decrease in $\mathrm{Al}_{2} \mathrm{O}_{3}$ from 13.6 to 12.7 percent accompanied by an increase in

$369 \quad \mathrm{MgO}$ from 18.5 to 19.1 percent.

370 Importantly, at pressures above $3 \mathrm{GPa}, \mathrm{Al}_{2} \mathrm{O}_{3}$ is compatible in all melting curves, increasing

371 slightly with increased melt production and increasing MgO. Consequently, the calculated

372 melting curves also do a better job of mimicking the experimental trends, although the range in

$373 \mathrm{MgO}$ is not as great. In particular, there is a progressive decrease in $\mathrm{Al}_{2} \mathrm{O}_{3}$ with increasing $\mathrm{MgO}$

374 as pressure increases. Of particular relevance to the problem of the constancy of $\mathrm{Al}_{2} \mathrm{O}_{3}$ at a given

$375 \mathrm{MgO}$ in Hawaiian shield-building lavas, is the fact that between 4 to $7 \mathrm{GPa}$, with increased

376 melting at a fixed pressure, both $\mathrm{Al}_{2} \mathrm{O}_{3}$ and $\mathrm{MgO}$ increase only slightly. For example, at $4 \mathrm{GPa}$,

377 melting from 10 to 20 percent results in an increase in $\mathrm{Al}_{2} \mathrm{O}_{3}$ of only 9.8 to 9.9 percent for an

378 increase in $\mathrm{MgO}$ from 18.6 to 19.0 percent. Similarly, at $4.5 \mathrm{GPa}$, melting from 10 to 20 percent

379 results in an increase in $\mathrm{Al}_{2} \mathrm{O}_{3}$ of only 8.3 to 8.5 percent for an increase in $\mathrm{MgO}$ from 20.7 to 21.2

380 percent. Comparable results are obtained for models of aggregated fractional melts.

381 Figure 4c allows us to qualitatively evaluate the possible role of polybaric melting. Small 
amounts of melt formed at around 4.5 to $4.0 \mathrm{GPa}$ will be on or close to the Hawaiian trend, but with larger degrees of partial melting at shallower depths ( $3 \mathrm{GPa})$ the melting trajectory will depart from the Hawaaian trend and $\mathrm{Al}_{2} \mathrm{O}_{3}$ in the accumulated melts will be too high. The situation will be exacerbated by continuing melting at even shallower depths ( $2 \mathrm{GPa})$. It appears, therefore, that melting is not polybaric, and that the melt composition is established at around $4 \mathrm{GPa}$. The situation is analogous to that described by Matzen et al., (2013) where the partitioning of Ni between olivine and melt during melting appears to be established at pressures greater than $3 \mathrm{GPa}$ rather than over a range of pressures as the magma ascends.

390 The answer to the conundrum of almost constant $\mathrm{Al}_{2} \mathrm{O}_{3}$ content at a given $\mathrm{MgO}$, in Hawaiian 391 shield-building tholeiites, irrespective of the history of the volcano or whether it belongs along the "Kea" or "Loa" trends, is I believe that melting takes place at sufficient depth, most probably at, or above, $4 \mathrm{GPa}(>120 \mathrm{~km})$ and firmly within the garnet stability field. At these depths both $\mathrm{Al}_{2} \mathrm{O}_{3}$ and $\mathrm{MgO}$ are compatible, resulting in only small changes in concentration with significant changes in melt production. The situation is analogous to that of the abundances of $\mathrm{Yb}$ and $\mathrm{Y}$ in Hawaiian tholeiitic lavas. Both elements have high garnet/melt Kd's. For example, Salters et al. 397 [2002] report garnet/melt Kd's for $\mathrm{Y}$ and $\mathrm{Yb}$ ranging between 1.6 to 2.4 and 3.0 to 5.1

398 respectively at 3.2 to $3.4 \mathrm{GPa}$. The garnet/melt $\mathrm{Kd}$ for $\mathrm{Al}_{2} \mathrm{O}_{3}$ is pressure-dependant (Appendix A) 399 ranging from around 1.9 at $3 \mathrm{GPa}$ to 3.7 at $7 \mathrm{GPa}$, intermediate between $\mathrm{Kd}$ values for $\mathrm{Y}$ and $\mathrm{Yb}$. $400 \quad$ Both $\mathrm{Y}$ and $\mathrm{Yb}$ are almost constant at a given $\mathrm{MgO}$ in Hawaiian tholeiites, and Hofmann and co401 workers [e.g. Hofmann et al, 1984; Hofmann, 1997] convincingly argue that high La/Yb, but in 402 particular almost constant $\mathrm{Yb}$ in $\mathrm{MgO}$ - normalized Hawaiian tholeiitic lavas, are indicative of an 403 origin from a garnet-bearing peridotite source. 
404 If the presence of garnet as a residual phase during melting is critical to the consistency of $\mathrm{Al}_{2} \mathrm{O}_{3}$

405 in Hawaiian shield-building tholeiites, it follows that the more garnet initially present in the

406 peridotite, the greater the probability of it being a residual phase. Increasing pressure increases

407 the stability and abundance of garnet in peridotite, but so also will relatively minor "fertilization"

408 of peridotite by reaction with melts derived from crustal components entrained within the plume

409 [e.g. Yaxley and Green, 1998]. There is a broad consensus that mantle plumes contain some re-

410 cycled oceanic crust plus minor sediments [e.g. Hofmann and White, 1982; Hauri, 1996;

411 Hofmann, 1997; Blichert-Toft et al., 1999; Huang and Frey, 2005; Fekiacova et al., 2007;

412 Jackson et al., 2012]. Exactly how much, and whether or not this re-cycled crustal component,

413 occurs as significant, distinct lithologies, such as eclogite or garnet pyroxenite, and whether it,

414 along with peridotite, is involved in the melting process, is a matter of vigorous debate [e.g.

415 Hauri,1996; Norman and Garcia, 1999; Takahashi and Nakajima, 2002; Huang and Frey, 2005;

416 Sobolev et al., 2005; Herzberg, 2006; Putirka et al., 2011; Jackson et al., 2012; Rhodes et al.,

417 2012; Matzen et al., 2013]. It is not the purpose of this paper to get involved in this debate.

418 However, if discrete bodies of eclogite or garnet pyroxinite co-exist with peridotite in an

419 ascending plume, they will melt before peridotite, at greater depths in the plume [e.g. Petermann

420 and Hirschmann, 2003; Sobolev et al., 2005] and these melts will react with peridotite [e.g.

421 Yaxley and Green, 1998], enhancing the clinopyroxene and garnet contents of the peridotite.

422 Such minor "fertilization" of peridotites will also contribute to the constancy of $\mathrm{Al}_{2} \mathrm{O}_{3}$ during

423 melting at shallower depths in the plume. It also follows that basaltic melts of secondary garnet

424 pyroxenites, produced by extreme fertilization of peridotite [e.g. Sobolev et al., 2005; Herzberg,

4252006 ], will also be characterized by almost constant $\mathrm{Al}_{2} \mathrm{O}_{3}$ at a given $\mathrm{MgO}$. It is beyond the 
scope of this paper to evaluate such models. Suffice it to say, there are several recent publications arguing that these convoluted models are not required to produce Hawaiian basaltic magmas: peridotite is sufficient [e.g. Putirka et al., 2011; Rhodes et al., 2012; Matzen et al., 2013; Rhodes 2015].

\subsection{What about the $\mathrm{SiO}_{2}$ conundrum?}

431 If the almost constant $\mathrm{Al}_{2} \mathrm{O}_{3}$ at a fixed $\mathrm{MgO}$ requires melting of garnet peridotite at pressures around $4 \mathrm{GPa}$, we now have combined trace and major element evidence supporting the formation of Hawaiian shield-building tholeiites from garnet peridotite deep within the mantle, probably at depths around $120 \mathrm{~km}$. Experimental melting of peridotite and basalts at these pressures shows that the resulting parental basaltic magmas have low $\mathrm{SiO}_{2}$ contents (see excellent summaries by Longhi, 2002; Stolper et al., 2004; Putirka et al., 2011). For example, the experiments of Walter [1998] between 3 and $5 \mathrm{GPa}$, produced melts from 44.8 to 46.9 percent $\mathrm{SiO}_{2}$. Similarly, above 3 GPa the melts of Salters et al., [2002] have around 45.6 to 46.0 percent $\mathrm{SiO}_{2}$. On the other hand, with the exception of Loihi [e.g. Garcia et al.,1995a] and compositionally similar lavas erupted 441 parental Hawaiian tholeiitic magmas, including those from the lower $\mathrm{SiO}_{2}$ "Kea" trend volcanoes, 442 have $\mathrm{SiO}_{2}$ contents exceeding $48 \%$. This is a pervasive problem in Hawaiian petrology [e.g. 443 Eggins, 1992; Takahashi et al., 1993; Wagner and Grove, 1998; Takahashi and Nakajima, 2002, 444 Stolper et al., 2004]. Experimental melting of basalts and peridotites show that high- $\mathrm{SiO}_{2}$ 445 parental magmas, that is, those with high enough $\mathrm{MgO}$ to crystallize $\mathrm{Fo}_{88-91}$, are produced at low 446 pressures $(<2.2 \mathrm{GPa})$ corresponding to depths of less than $70 \mathrm{~km}$ and are in equilibrium with a 447 harzburgite residue [e.g. Herzberg and O'Hara, 2002; Maaloe, 2004]. They are not in 
448 equilibrium with garnet lherzolite at any pressure.

449 In order to explain this paradox, a number of authors have appealed to melt reaction between 450 ascending magma and overlying depleted harzburgite [e.g. Eggins, 1992; Wagner and Grove, 451 1997; Stolper et al., 2004; Rhodes, 2015]. The basic concept is that low-SiO $\mathrm{S}_{2}$ elts, produced by 452 melting garnet lherzolite at depths of $90-130 \mathrm{~km}$ within the plume, interact on ascent with 453 overlying, depleted, residual harzburgite (the residue of prior melt extraction within the plume).

454 The reaction involves the dissolution of orthopyroxene from the harzburgite, compensated for by 455 the crystallization of olivine from the melt. As noted by Stolper et al. [2004], if melt - harzburgite 456 reaction is a prevailing process in the Hawaiian plume, then high- $\mathrm{SiO}_{2}$ magmas will be dominant 457 and low-SiO 2 magmas will be the exception. Wagner and Grove [1997] demonstrated that the 458 reaction of a low- $\mathrm{SiO}_{2}$ melt with harzburgite to produce a Kilauea parental magma had little 459 influence on the garnet diagnostic $\mathrm{La} / \mathrm{Yb}$. The only effect was to slightly decrease the abundance 460 of both elements. Similarly, Rhodes [2015] showed that reaction of an inferred low-SiO${ }_{2} \mathrm{Mauna}$ 461 Loa parental magma (similar to Loihi) with residual harzburgite had little influence on the 462 isotopic ratios of ${ }^{87} \mathrm{Sr} /{ }^{86} \mathrm{Sr},{ }^{143} \mathrm{Nd} /{ }^{144} \mathrm{Nd}$ and ${ }^{206} \mathrm{~Pb} /{ }^{204} \mathrm{~Pb}$.

463 But what about $\mathrm{Al}_{2} \mathrm{O}_{3}$ ? Will reaction of a low-SiO 2 parental melt with overlying residual 464 harzburgite influence the constancy of $\mathrm{Al}_{2} \mathrm{O}_{3}$ resulting from melting of garnet peridotite at greater 465 depths? Using the reactants from table 4 of Wagner and Grove [1997), 4 GPa experimental melt 466 compositions $\left(19 \% \mathrm{MgO}\right.$ and $\left.9.5 \% \mathrm{Al}_{2} \mathrm{O}_{3}\right)$ and olivine $\left(\mathrm{Fo}_{90}\right)$ from Walter [1998], and reactant 2.4 $467-2.8 \mathrm{GPa}$ orthopyroxene $\left(31 \% \mathrm{MgO}, 6.2 \% \mathrm{Al}_{2} \mathrm{O}_{3}\right)$ from Salters et al. [2002] results in a shallow 468 reactant melt $\left(15.1 \% \mathrm{MgO}, 10.8 \% \mathrm{Al}_{2} \mathrm{O}_{3}\right)$ that is firmly located on the Hawaiian $\mathrm{MgO}$ vs $\mathrm{Al}_{2} \mathrm{O}_{3}$ 469 trend (Fig. 5). Stolper et al., [2004] suggest that clinopyroxene might also be a reactant in 
addition to orthopyroxene. Figure 5 shows that dissolution of clinopyroxene should result in a

471 slight decrease in $\mathrm{Al}_{2} \mathrm{O}_{3}$, compensating from the slight increase attributed to orthopyroxene.

472 The $\mathrm{MgO}$ content of this inferred melt (15\%) is by design close to that of the most primitive

473 picritic glasses yet found in Hawaii [Clague et al., 1991]. Also, because of the relative uniformity

474 of $\mathrm{FeO}$ in Hawaiian tholeiites, a magma with around $15 \% \mathrm{MgO}$ should crystallize olivines of

475 around $\mathrm{Fo}_{88-89}$ (assuming a $\mathrm{KD}_{\mathrm{Fe}-\mathrm{Mg}}$ of 0.32$)$ at the high end of the olivine phenocryst range $\left(\mathrm{Fo}_{87-91}\right)$

476 in Hawaiian picrites [e.g. Wilkinson and Hensel., 1988; Helz, 1987; Baker et al., 1996; Garcia et

477 al., 1995; Garcia, 1996; Putirka, 2005].

478 In contrast with $\mathrm{Al}_{2} \mathrm{O}_{3}, \mathrm{Ni}$ is highly compatible in both the crystallizing olivine and the reactant

479 orthopyroxene in the melt - harzburgite reaction, and one might anticipate difficulties with the

480 model. This is the position taken by Huang and Frey [2005] who argue that the melt - peridotite

481 reaction cannot account for the differences in $\mathrm{SiO}_{2}$ in Hawaiian magmas because there is not a

482 significant difference in Ni concentrations between high and low $\mathrm{SiO}_{2}$ lavas from Mauna Kea or

483 between the Maakapuu and Kalihi stage lavas of Koolau. However, there is considerable

484 uncertainty concerning: which kd's for olivine and orthopyroxene are appropriate [e.g Beattie et

485 al., 1991; Putirka et al., 2011; Matzen et al., 2013]; the Ni content of the source peridotite (1900 -

$4862360 \mathrm{ppm}$ ); and the Ni content of the parental melts [e.g. Sobolev et al., 2005; Putirka et al.,

487 2011; Rhodes et al., 2012; Herzberg et al., 2013). It is beyond the scope of this paper to evaluate

488 these here, but this will be discussed in a subsequent publication.

489 There is a serious problem with both the melt reaction model, advocated here, and with the widely

490 preferred alternative of simply melting peridotite at pressures $<2.2 \mathrm{GPa}$. Both must occur at

491 lithospheric depths. Beneath Hawaii the lithosphere is thought to be $88 \mathrm{~km}$ to $110 \mathrm{~km}$ thick [e.g. 
Priestly and Tilmann, 1999; Li et al., 2004]. Isotopic data, especially Os, Pb and Hf, preclude

493 involvement of the Cretaceous lithosphere overlying the Hawaiian plume in the melting process

494 [e.g. Hauri et al., 1996; Lassiter and Hauri, 1996; Blichert-Toft et al., 1999; Abouchami et al.,

495 2000; Fekiacova et al. 2007]. Therefore, unless the depth estimates for melt segregation are

496 unrealistic, both models require involvement of plume-derived materials. There are two possible

497 explanations: the lithosphere has been thinned and seismic resolution is insufficient to distinguish

498 between lithosphere and underlying buoyant depleted plume harzburgite; or plume derived melts

499 and associated residual harzburgite intrude deep into the lithosphere [Phipps Morgan et al., 1995;

$500 \quad$ Wagner and Grove, 1997].

501 In summary, this is a plausible explanation for maintaining the almost constant $\mathrm{Al}_{2} \mathrm{O}_{3}$ content of

502 parental Hawaiian shield-building tholeites by melting within a deep garnet-bearing peridotite

503 plume source, followed by melt reaction, during ascent with residual harzburgite to produce the

504 almost ubiquitous high-SiO${ }_{2}$ magmas that characterize shield-stage growth of Hawaiian

505 volcanoes. The less common low- $\mathrm{SiO}_{2}$ lavas of Loihi and Mauna Kea may have avoided reaction

506 with the residual harzburgite by flow through olivine-lined channels formed by prior melt-

507 harzburgite interaction [e.g. Kelemen et al., 1995; Stolper et al., 2004]. In the case of Loihi, at the 508 leading edge of the plume, there is probably very little residual harzburgite available for reaction.

\section{$509 \quad$ 5. Conclusions}

510 1. Study of over 1,800 major element analyses from my XRF laboratory of Hawaiian shield511 building tholeiites shows that the variation in the $\mathrm{Al}_{2} \mathrm{O}_{3}$ content, at a given $\mathrm{MgO}$ content is 
very small, about one weight percent at 10 percent $\mathrm{MgO}$. In the case of volcanoes for which we have long magmatic histories (e.g. Kilauea, about 24 ka; Mauna Kea, about 360 $\mathrm{ka}$; Mauna Loa, about $600 \mathrm{ka}$ ) there is no significant difference in $\mathrm{Al}_{2} \mathrm{O}_{3}$ over time, nor are there differences between subaerial and submarine lavas, or magma types with different $\mathrm{SiO}_{2}$ content or isotopic ratios. There is substantial overlap in $\mathrm{Al}_{2} \mathrm{O}_{3}$ in lavas between volcanoes belonging to the isotopically distinct "Loa" and "Kea" trends, but "Kea" trend volcanoes tend to erupt lavas with slightly lower $\mathrm{Al}_{2} \mathrm{O}_{3}$ relative to $\mathrm{MgO}$ than those from the "Loa" trend. Nonetheless, the average difference between the two trends is only about 0.2 weight percent (Fig. 3). Post-shield lavas from both the "Loa" and "Kea" trends are distinctly higher in $\mathrm{Al}_{2} \mathrm{O}_{3}$ relative to $\mathrm{MgO}$ than the earlier, shield-stage lavas.

2. The constancy of $\mathrm{Al}_{2} \mathrm{O}_{3}$ at a given $\mathrm{MgO}$ is contrary to what we anticipate from melting in a thermally-zoned and heterogeneous mantle plume. There are significant differences of major elements, trace elements and isotopic ratios between individual volcanoes, and melt production and segregation at different depths as individual volcanoes are transported by the northwest-moving Pacific plate over the plume.

529 3. The vast majority of Hawaiian shield-building tholeiites, including those from both "Kea" and "Loa" trend volcanoes, are high in $\mathrm{SiO}_{2}$ content. Experimental melting studies of sometimes over the growth of an individual volcano. These differences are usually attributed to different proportions of source components in the plume, and to differences in peridotites and basalts indicate that high- $\mathrm{SiO}_{2}$ parental magmas are produced at relatively shallow depths $(<70 \mathrm{~km})$ in the mantle, with a harzburgite residue. Under such conditions $\mathrm{Al}_{2} \mathrm{O}_{3}$ will be incompatible and varying melting conditions should result in a range in 
$\mathrm{Al}_{2} \mathrm{O}_{3}$ content in the magmas. As shown here, this is clearly not the case! The most plausible explanation is that $\mathrm{Al}_{2} \mathrm{O}_{3}$ is not incompatible during melting. The $\mathrm{Kd}$ 's for garnet/melt correlate with both temperature and pressure, ranging from 1.9 at $3 \mathrm{GPa}$ to 3.7 at $7 \mathrm{GPa}$. These are similar to the garnet/melt $\mathrm{Kd}$ 's for $\mathrm{Y}$ and $\mathrm{Yb}$. This requires melting to take place in the presence of garnet, from a garnet peridotite source, at depths exceeding $90 \mathrm{~km}$, probably around $120 \mathrm{~km}$.

Because both $\mathrm{Al}_{2} \mathrm{O}_{3}$ and $\mathrm{MgO}$ are compatible during melting at these depths, there will be little variation in both oxides with varying amounts of melt production, giving rise to the remarkable uniformity of $\mathrm{Al}_{2} \mathrm{O}_{3}$ at a given $\mathrm{MgO}$ in Hawaiian shield-building tholeiites. If the small difference in $\mathrm{Al}_{2} \mathrm{O}_{3}$ between "Kea" and "Loa" trend lavas is significant (Fig. 3) it could imply that "Loa' trend magmas result from slightly greater amounts of melting than "Kea" trend magmas, in agreement with the slightly lower concentrations of incompatible elements in "Loa" trend magmas. On the other hand, the markedly higher $\mathrm{Al}_{2} \mathrm{O}_{3}$ content of post-shield lavas relative to shield-stage lavas probably reflects garnet-free melting at the shallower $(<3 \mathrm{GPa})$ and cooler margins of the plume.

4. Relatively constant normalized $\mathrm{Yb}$, and other HREE, abundances have been used as a strong argument for a garnet peridotite source for Hawaiian shield-stage magmas. We now have $\mathrm{Al}_{2} \mathrm{O}_{3}$, a major element oxide, providing the same information. These conclusions are contradictory to those from high-pressure experimental melting of peridotites and basalts. These experiments show that high- $\mathrm{SiO}_{2}$ tholeiites, volumetrically the most abundant during the shield-building stage, were never in equilibrium with garnet, and were probably produced at depths of $70-90 \mathrm{~km}$. In order to reconcile these two 
contrasting arguments it appears possible that a low- $\mathrm{SiO}_{2}$ parental magma, produced by melting garnet peridotite at depths of $100-120 \mathrm{~km}$, reacts with a buoyant, depleted, harzburgite residue from prior melting within the plume, as the magma ascends through the upper regions of the plume. The result is a high- $\mathrm{SiO}_{2}$ tholeiite that retains the garnet signature of its deeper origins.

$561 \quad$ Acknowledgments

562 The data for this work were obtained over many years through funding by the National Science

563 Foundation. Special thanks to Pete Lipman, Jack Lockwood, Frank Trusdell and Tina Neal for 564 sharing their volcanoes with me, and for guidance and friendship in the field. Mike Garcia, 565 provided good companionship, many samples for this study, and was responsible for the 566 submarine exploration of Mauna Loa. Pete Dawson, Mike Vollinger and John Sweeney kept the 567 instruments running and produced the highest quality data. Thoughtful, reviews by Keith Putirka, 568 Vince Salters, Associate Editor Shichaun Huang, and Claudia Rhodes, are greatly appreciated and 569 have significantly improved the quality of this paper. This paper is dedicated to Fred Frey. I have 570 known Fred for over forty years, first as a scientific hero, and later as a colleague and friend. I 571 hope he will find this paper sufficiently provocative.

\section{Figure Captions}

Figure 1. Variations of $\mathrm{Al}_{2} \mathrm{O}_{3}$ with $\mathrm{MgO}$ in "Loa" trend volcanoes: (a) Mauna Loa; (b) Loihi; 
data have been screened for samples that are considered to be altered $\left(\mathrm{K}_{2} \mathrm{O} / \mathrm{P}_{2} \mathrm{O}_{5}<1.0\right)$ or have

578 undergone fractionation beyond olivine control $(\mathrm{MgO}<6.8 \%)$.

579 Figure 2. Variations of $\mathrm{Al}_{2} \mathrm{O}_{3}$ with $\mathrm{MgO}$ in "Kea" trend volcanoes: (a) Kilauea; (b) Mauna Kea

$580 \quad$ (shield-stage lavas only); (c) Kilauea, Mauna Kea and Kohala shield-stage lavas combined; (d)

581 Mauna Kea post-shield lavas. In figures (a) and (b) the regression lines are for Kilauea and

582 Mauna Kea respectively, and in (c) and (d) all the Kea shield-stage data are combined. The data

583 have been screened for samples that are considered to be altered $\left(\mathrm{K}_{2} \mathrm{O} / \mathrm{P}_{2} \mathrm{O}_{5}<1.0\right)$ or have

584 undergone fractionation beyond olivine control $(\mathrm{MgO}<6.8 \%)$.

585 Figure 3. Comparison of variations of $\mathrm{Al}_{2} \mathrm{O}_{3}$ with $\mathrm{MgO}$ in "Loa" and "Kea" trend volcanoes,

586 with regression lines for both trends. The data have been screened for samples that are considered 587 to be altered $\left(\mathrm{K}_{2} \mathrm{O} / \mathrm{P}_{2} \mathrm{O}_{5}<1.0\right)$ or have undergone fractionation beyond olivine control $(\mathrm{MgO}<$ $588 \quad 6.8 \%$ ).

589 Figure 4. Variation of $\mathrm{Al}_{2} \mathrm{O}_{3}$ with $\mathrm{MgO}$ in peridotite and basalt melting experiments and in 590 numerical melt modeling. (a) Parameterization of harzburgite melting at pressures ranging from 1 591 to $6 \mathrm{GPa}$ from Herzberg and O'Hara (2002). Both increase in pressure and in melt production 592 result in significant increases in $\mathrm{MgO}$ and corresponding decreases in $\mathrm{Al}_{2} \mathrm{O}_{3}$. (b) Melting 593 experiments on peridotite [Walter, 1998] and picrites [Salters et al., 2002] between $<3$ and 7 594 GPa. Only melts produced by less than 50\% melting are shown. The vectors of increasing melt 595 production are shown for different pressures. At $3 \mathrm{GPa}$ or less, increased melting results in 596 increase in $\mathrm{MgO}$ and decrease in $\mathrm{Al}_{2} \mathrm{O}_{3}$, similar to harzburgite melting. At pressures above $3 \mathrm{GPa}$ 597 both $\mathrm{MgO}$ and $\mathrm{Al}_{2} \mathrm{O}_{3}$ increase with increased melt production, indicating that garnet is a residual 598 phase. Additionally, the slope of the melting trend tends to increase with increasing pressure 
599 reflecting the greater stability of garnet at increased pressure. (c) Comparison of non-modal batch 600 melting models with the experimental melting data summarized in (b). The melting intervals are 601 at 1, 10, 20 and 30 percent. At $3 \mathrm{GPa}$ or less, progressive melting results in increase in $\mathrm{MgO}$ and 602 decrease in $\mathrm{Al}_{2} \mathrm{O}_{3}$, and there is a significant difference in $\mathrm{MgO}$ and $\mathrm{Al}_{2} \mathrm{O}_{3}$ between melt intervals. 603 Above $3 \mathrm{GPa}$ both $\mathrm{MgO}$ and $\mathrm{Al}_{2} \mathrm{O}_{3}$ increase with progressive melting and the differences between 604 melt intervals are very small. The curving bold arrow schematically shows a path of polybaric 605 melt production between 4.5 and $<3.0 \mathrm{GPa}$. See text for details. The experimental and modeling 606 data are compared with the combined trend for "Loa" and "Kea" lavas in all three figures (small 607 grey crosses).

608 Figure 5. Reaction of a $4 \mathrm{GPa}$ garnet peridotite melt with harzburgite using the reaction of 609 Wagner and Grove [1997, Table 4]. The olivine is an average 4 GPa olivine from Walter [1998] 610 and the orthopyroxene and clinopyroxene are average $2.4-2.8 \mathrm{GPa}$ compositions from Salters et 611 al. [2002]. See text for details.

\section{$612 \quad$ References}

613 Albarède, F. (1992) How deep do common basaltic magmas form and differentiate? J. Geophys. $614 \quad$ Res. 97, 10997-11009, 1992.

615 Abouchami, W., Galer, S. J .G., and Hofmann, A. W. (2000) High precision lead isotope 616 systematics of lavas from the Hawaiian Scientific Drilling Project, Chem. Geol. 169, 187-209

617 Abouchami, W., Hofmann, A. W., Galer, S. J. G., Frey, F. A., Eisele, J. and Feigenson, M.

618 (2005) $\mathrm{Pb}$ isotopes reveal bilateral asymmetry in the Hawaiian plume, Nature, 434, 851-856.

619 Baker, M. B., Alves, S., Stolper, E. M. (1996) Petrography and petrology of the Hawaii Scientific 620 Drilling Project lavas: Inferences from olivine phenocryst abundances and compositions, $J$. 
621 Geophys. Res.101, 11,715-11,727.

622 Beattie, P., Ford, C. and Russell, D. (1991) Partition coefficients for olivine-melt and

623 orthopyroxene-melt systems. Contrib. Mineral Petrol. 109, 212-224.

624 Blichert-Toft, J., Frey, F. A. and Albarède, F. (1999) Hf isotope evidence for pelagic sediments in 625 the source of Hawaiian basalts, Science, 285, 879-882.

626 Carmichael, I.S.E., Nicholls, J. and Smith, A. L. (1970) Silica activity in igneous rocks, Am. 627 Mineral. 55, 246-263.

628 Chen, C.-Y., Frey, F. A., Rhodes, J. M. and Easton, R. M. (1996) Temporal geochemical 629 evolution of Kilauea Volcano: Comparison of Hilina and Puna basalt, in Geopys. Monogr. Series.

630 95, 161-181, edited by A. Basu and S. R. Hart, AGU, Washington, D.C.

631 Clague, D. A., Weber, W. S. and Dixon, J. E. (1991) Picritic glasses from Hawaii, Nature, 353, $632 \quad 553-556,1991$.

633 Clague, D. A., Moore, J. G., Dixon, J. E. and Friesen, W. B., Petrology of submarine lavas from 634 Kilauea’s Puna Ridge, Hawaii, J. Petrol. 36, 299-349, 1995.

635 DePaolo, D. J., and E. M. Stolper (1996), Models of Hawaiian volcano growth and plume 636 structure: Implications of results from the Hawaii Scientific Drilling Project, J. Geophys Res., $637 \mathbf{1 0 1}, 11,643-11,654$.

638 Eggins, S. M. (1992) Petrogenesis of Hawaiian tholeiites. 2. Aspects of dynamic melt 639 segregation, Contrib. Mineral. Petrol. 110, 387-397.

640 Eisele, J., Abouchami, W., Galer, S. J. G. and Hofmann, A. W. (2003) The 320 ky Pb isotoe 641 evolution of the Mauna Kea lavas recorded in the HSDP-2 drill core, Geochem. Geophys. 642 Geosyst. 4, doi: 10.1029/2002GC000339, 2003. 
643 Farnetani, C. G. and Hofmann, A. W. (2010) Dynamics and internal structure of the Hawaiian

644 plume, Earth. Planet. Sci. Lett. 295, 231-240.

645 Feigenson, M. D., Hofmann, A. W. and Spera, F. J. (1983) Case studies on the origin of basalt

646 11. The transition from tholeiite to alkalic volcanism on Kohala volcano, Hawaii, Contrib.

647 Mineral. Pet. 84, 390-405.

648 Fekiacova, Z., Abouchami, W., Galer, S. J. G., Garcia, M. O. and Hofmann, A. W. (2007) Origin

649 and temporal evolution of Koolau Volcano, Hawaii: Inferences from isotopic data on the Koolau

650 Scientific Drilling Project (KSDP), the Honolulu Volcanics and ODP Site 843, Earth Planet. Sci.

$651 \quad$ Lett. 261, 65-83.

652 Frey, F.A., Garcia, M.O., Wise, W.S., Kennedy, A., Gurriet, P. and Albarede, F. (1991) The

653 evolution of Mauna Kea Volcano, Hawaii: Petrogenesis of tholeiitic and alkalic basalts, $J$.

654 Geophys. Res. 96, 14,347-14,375.

655 Frey, F. A., and Rhodes, J. M. (1993) Inter-shield geochemical differences among Hawaiian

656 volcanoes: Implications for source compositions, melting processes and magma ascent paths,

657 Philos. Trans. R. Soc. London Part A, 342, 121-136.

658 Frey, F. A., Garcia, M. O. and Roden, M. F. (1994) Geochemical characteristics of Koolau

659 volcano: Implications of intershield geochemical differences among Hawaiian volcanoes,

660 Geochim. Cosmochim. Acta 58, 1441-1462.

661 Garcia, M. O. (1996) Petrography and olivine and glass chemistry of lavas from the Hawaii

662 Scientific Drilling Project, J. Geophys. Res. 101, 11,701-11,713. 
663 Garcia, M. O., Muenow, K., Aggrey, J. and O’Neil, J. (1989) Major element, volatile, and stable

664 isotope geochemistry of Hawaiian submarine tholeiitic glasses, J. Geophys. Res. 94, 10,526-10,538.

665 Garcia, M. O., Foss, D. J. P., West, H. B., Mahoney, J. (1995a) Geochemical and isotopic

666 evolution of Loihi volcano, Hawaii, Journal of Petrology, 41, 1647-1674.

667 Garcia, M. O., Hulsebosch, T. and Rhodes, J. M. (1995b) Olivine-rich submarine basalts from the

668 Southwest Rift Zone of Mauna Loa volcano: Implications for magmatic processes and

669 geochemical evolution, in Mauna Loa Revealed: Structure, Composition, History, and Hazards,

670 Geophys. Monogr. Ser., 92, edited by J. M. Rhodes and J. P. Lockwood, pp. 219-239, AGU,

671 Washington, D. C.

672 Garcia, M. O. (1996) Petrography and olivine and glass chemistry of lavas from the Hawaii

673 Scientific Drilling Project, J. Geophys. Res. 101, 11,701-11,713.

674 Garcia, M. O., Rubin, K., Norman, M. D., Rhodes, J. M., Graham, D. W, and Spencer, K. (1998)

675 Petrology and geochronology of basalt breccia from the 1996 earthquake swarm of Loihi

676 Seamount, Hawaii: Magmatic history of its 1996 eruption, Bull. Volcanol, 59, 577-592.

677 Garcia, M.. O, Pietruszka, A. J., Rhodes, J. M. and Swanson. K. (2000) Magmatic processes

678 during the prolonged Puu Oo eruption of Kilauea Volcano, Hawaii, Journal of Petrology, 41, $679 \quad 967-990$.

680 Garcia, M. O., Hanano, D., Flinders, A., Weis, D., Ito, G. and Kurz, M. D. (2012) Age, geology, 681 geophysics and geochemistry of Mahukona volcano, Hawaii, Bull. Volc. 74, 1445-1463.

682 Haskin, E. H. and Garcia, M. O. (2004) Scientific drilling reveals geochemical heterogeneity 683 within the Koolau shield, Hawaii, Contrib. Mineral. Petrol. 147, 162-188. 
684 Hauri, E. H. (1996) Major element variability in the Hawaiian mantle plume, Nature, 283, 415685419.

686 Hauri, E. H., Lassiter, J. C. and DePaolo, D. J. (1996) Osmium isotope systematics of drilled 687 lavas from Mauna Loa, Hawaii, J. Geophys. Res. 101, 11,793-11,806.

688 Helz, R. T. (1987) Diverse olivine types in lavas of the 1959 eruption of Kilauea volcano and 689 their bearing on eruption dynamics. In: Decker, R. W., Wright, T. L. and Staufer, P. H. (eds.) $690 \quad$ Volcanism at Hawaii. US Geol. Surv. Prof. Paper 1350, 691-722.

691 Herzberg, C. (2006) Petrology and thermal structure of the Hawaiian plume from Mauna Kea 692 volcano, Nature 444, 605-609.

693 Herzberg, C. and O’Hara, M. J. (2002) Plume-associated ultramafic magmas of phanerozoic age, 694 J. Petrol. 43, 1857-1853.

695 Herzberg, C., Asimov, P. D., Ionov, D. A., Vidito, C., Jackson, M. G. and Geist, D. (2013)

696 Nickel and helium evidence for melt above the core-mantle boundary, Nature 493, 393-397.

697 Hofmann, A. W. (1997) Mantle geochemistry; the message from oceanic volcanism, Nature 385, $698 \quad 219-229$.

699 Hofmann, A. W. and White, W. M. (1982) Mantle plumes from ancient oceanic crust, Earth. $700 \quad$ Planet. Sci. Lett. 57, 227-284.

701 Hofmann, A. W. and Farnetani, C. G. (2013) Two views of the Hawaiian plume structure, 702 Geochem. Geophys. Geosyst. 14. doi:10.1002/2013GC004942.

703 Hofmann, A. W., Feigenson, M. D. and Raczek, I. (1984) Case studies on the origin of basalt, III, 704 Petrogenesis of the Mauna Ulu eruption, Kilauea, 1969 - 1971, Contrib. Mineral. Petrol. 88, 24 70535. 
706 Holcomb, R.T. (1987) Eruptive history and long-term behavior of Kilauea Volcano, in Volcanism

707 in Hawaii, edited by R.W. Decker et al., U. S. Geol. Surv. Prof. Pap. 1350, pp 261-250.

708 Huang S. and Frey F. A. (2005) Recycled oceanic crust in the Hawaiian Plume: evidence from

709 temporal geochemical variations within the Koolau shield, Contrib. Mineral. Petrol. 149,

$710 \quad 556-575$. doi:10.1007/s00410-005-0664-9.

711 Huang, S., Frey, F. A., Blichert-Toft, J.,Fodor, R. V., Bauer, G. R. and Xu, G. (2005) Enriched

712 components in the Hawaiian plume: evidence from Kahoolawe Volcano, Hawaii, Geochem.

713 Geophys. Geosyst. 6. doi:10.1029/2005GC001012.

714 Jackson, E. D., Silver, E. A. and Dalrymple, G. B. (1972) Hawaiian-Emperor chain and its

715 relationship to Cenozoic circum-pacific tectonics, Geol. Soc. Am. Bull. 83, 601-618.

716 Jackson, M. G., Weis, D. and Huang, S. (2012) Major element variation in Hawaiian shield lavas:

717 Source features and perspectives from global ocean island (OIB), Geochem. Geophys. Geosyst.,

718 13, doi:10.1029/2012GC004268.

719 Jicha, B. R., Rhodes, J. M., Singer, B. S. and Garcia, M. O. (2012) ${ }^{40} \mathrm{Ar} /{ }^{\beta 9} A r$ geochronology of

720 submarine Mauna Loa volcano, Hawaii, J. Geophys. Res.117, B09204,

721 doi:10,1029/2012JB009373

722 Kelemen, P. B., Shimizu, N. and Salters, V. J. (1995) Extraction of mid-ocean ridge basalt from

723 the upwelling mantle by focused flow of melt in dunite channels, Nature, 375, 747-753.

724 Kushiro, I. (1996) Partial melting of a fertile mantle peridotite at high pressures: an experimental 725 study using diamond aggregates, In Reading the Isotopic Code. Geophys. Monogr. Ser., 95, edited 726 by Basu, A. and Hart, S., AGU, Washington, D. C. 
727 Lassiter J. C. and Hauri, E. H. (1996) Osmium isotope variations in Hawaiian lavas: Evidence for 728 recycled oceanic lithosphere in the Hawaiian plume, Earth Planet. Sci. Lett., 164, 483-496.

729 Lassiter, J. C., DePaolo, D. J. and Tatsumoto, M. (1996) Isotopic evolution of Mauna Kea

730 volcano: Results from the initial phase of the Hawaii Scientific Drilling Project, J. Geophys. Res.

$731 \mathbf{1 0 1}, 11,769-11,780$.

732 Lee, C-T, Luffi, P., Plank, T. Dalton, H. and Leeman, W. P. (2009) Constraints on the depth and 733 temperatures of basaltic magma generation on Earth and other terrestrial planets using a new 734 barometer for mafic magmas, Earth Planet. Sci. Lett. 279, 20-33.

735 Li, X., Kind, R., Yuan, X., Wölbern, I. and Hanka, I. (2004) Rejuvenation of the lithosphere by 736 the Hawaiian plume, Nature 427, 827-829.

737 Lipman, P. W., Rhodes, J. M. and Dalrymple, G. B. (1991) The Ninole Basalt - implications for 738 the structural evolution of Mauna Loa volcano, Hawaii, Bull. Volcanol. 53, 1-19.

739 Lockwood, J. P. (1995), Mauna Loa eruptive history: The preliminary radiocarbon record, in 740 Mauna Loa Revealed: Structure, Composition, History and Hazards, Geophys. Monogr. Ser., 92, 741 edited by J. M. Rhodes and J. P. Lockwood, pp. 45-80, AGU, Washington, D. C.

742 Longhi, J. (2002) Some phase equilibrium Systematics of lherzolite melting, Geochem. Geophys. 743 Geosyst., 3, doi10,1029/2001GC000204.

744 Maaloe, S. (2004) The PT-phase relations of an MgO-rich Hawaiian tholeiite: the composition of 745 primary Hawaiian tholeiites, Contrib. Mineral. Petrol. 148, 236-246.

746 Marske, J. P., Pietruzska, A. J., Weis, D., Garcia, M. O. and Rhodes, J. M. (2007) Rapid passage 747 of a smale-scale mantle heterogeneity through the melting regions of Kilauea and Mauna Loa 748 volcanoes, Earth Planet. Sci. Lett. 259, 34-50. 
749 Matzen, A. K., Baker, M. B., Beckett, J. R. and Stolper, E. M. (2013) The temperature and

750 pressure dependence of nickel partitioning between olivine and silicate melt, J. Petrol, 54, 25217512545.

752 Moore, J. G. and Clague, D. A. (1992) Volcano growth and evolution of the island of Hawaii, 753 Geol. Soc. Am. Bull. 104, 1471-1484.

754 Moore, E. W. and Morris, J. (1996) Geological map of the island of Hawaii, U.S. Geological 755 Survey IMAP 2524-A, scale 1:100,000.

756 Murata, K. J. and Richter, D. H. (1966) Chemistry of the lavas of the 1959-60 eruption of 757 Kilauea volcano, Hawaii, U.S. Geol. Surv. Prof. Pap. 357-A, 26 pp.

758 Norman, M. D. and Garcia, M. O. (1999) Primitive magmas and source characteristics of the 759 Hawaiian plume: petrology and geochemistry of shield picrites, Earth Planet. Sci. Lett., 168, $27-$ 76044.

761 Norrish, K. and Hutton, J. T. (1969) An accurate X-ray spectrographic method for the analysis of 762 a wide range of geological samples, Geochim. Cosmochim. Acta, 33, 431-464.

763 Petermann, M. and Hirschmann, M. M. (2003) Partial melting experiments on a MORB-like 764 pyroxenite between 2 and $3 \mathrm{GPa}$ : Constraints on the presence of pyroxenite in basalt source 765 regions from solidus location and melting rate, J. Geophys. Res. 108, doi:10.1029/2000JB000118.

766 Phipps Morgan, J., Morgan, W. J. and Price, E. (1995) Hotspot melting generates both hotspot 767 volcanism and hotspot swell? J. Geophys. Res. 100, 8046-8062.

768 Pietruszka, A. J. and Garcia, M. O. (1999) A rapid fluctuation in the mantle source and melting 769 history of Kilauea volcano inferred from the geochemistry of its historical summit lavas (1790 770 1982), J. Petrol. 40, 1321-1342. 
771 Powers, H. A. (1955) Composition and origin of basaltic magmas on the Hawaiian islands,

772 Geochem. Cosmochem. Acta, 7, 77-107.

773 Priestly, K. and Tilmann, F. (1999) Shear-wave structure of the lithosphere above the Hawaiian

774 hot spot from two-station Rayleigh wave phase velocity measurements, Geophys. Res. Lett. 26,

$775 \quad 1493-1496$.

776 Putirka, K. D. (2005) Mantle potential temperatures at Hawaii, Iceland, and the mid-ocean ridge

777 system, as inferred from olivine phenocrysts: Evidence for thermally driven mantle plumes,

778 Geochem. Geophys. Geosyst., 6, Q05L08, doi:10.1029/2005GC000915434.

779 Putirka, K., Ryerson, E. J., Perfit, M. and Ridley, W. I. (2011) Mineralogy and composition of the $780 \quad$ oceanic mantle, J. Petrol. 52, 279-313.

781 Quane, S. L., Garcia, M. O., Guillou, H. and Hulsebosch, T. P. (2000) Magmatic history of the 782 east rift zone of Kilauea volcano, Hawaii based on drill core from SOH 1, J. Volc. Geotherm. Res. $783 \quad \mathbf{1 0 2}, 319-338$.

784 Rhodes, J. M. (1995) The 1852 and 1868 Mauna Loa picrite eruptions: Clues to parental magma 785 compositions and the magmatic plumbing system, in Mauna Loa Revealed: Structure,

786 Composition, History and Hazards, Geophys. Monogr. Ser., 92, edited by J. M. Rhodes and J. P. 787 Lockwood, pp. 241-262, AGU, Washington, D. C.

788 Rhodes, J. M. (1996) The Geochemical Stratigraphy of lava flows sampled by the Hawaii 789 Scientific Drilling Project, J. Geopys. Res., 101, 11,729-11,746.

790 Rhodes, J. M. (2015) Major element and isotopic variations in Mauna Loa magmas over 600 ka: 791 Implications for magma generation and source lithology as Mauna Loa transits the Hawaiian 
792 plume, in Hawaiian Volcanoes. From Source to Surface, Geophys. Monogr. Ser., 208, edited by

793 Carey, R., Cayol, V., Poland, M. and Weis, D., pp.59-78, AGU, Washington, D. C.

794 Rhodes, J. M., Wenz, K. P., Neal, C. A., Sparks, J. W. and Lockwood, J. P. (1989) Geochemical 795 evidence for invasion of Kilauea's plumbing system by Mauna Loa magmas, Nature, 337, 257796260.

797 Rhodes, J. M. and Hart, S. R. (1995) Episodic trace element and isotopic variations in historical

798 Mauna Loa lavas: Implications for magma and plume dynamics, in Mauna Loa Revealed:

799 Structure, Composition, History and Hazards, Geophys. Monogr. Ser. 92, p.263-288, edited by

800 Rhodes, J. M. and Lockwood, J. P., AGU, Washington, D.C.

801 Rhodes, J. M., and Vollinger, M. J. (2004), Composition of basaltic lavas sampled by phase-2 of 802 the Hawaii Scientific Drilling Project: Geochemical stratigraphy and magma types, Geochem. 803 Geophys. Geosyst., 5, Q03G13, doi:10.1029/2002GC000434.

804 Rhodes, J. M., Huang, S., Frey, F. A., Pringle, M. and Xu, G. (2012) Compositional diversity of 805 Mauna Kea shield lavas recovered by the Hawaii Scientific Drilling Project: Inferences on source 806 lithology, magma supply, and the role of multiple volcanoes, Geochem. Geophys. Geosyst., 13, 807 Q03014, doi:10.1029/2011GC003812.

808 Ribe, N. M. and Christenson, U. R. (1999) The dynamic origin of Hawaiian volcanism, Earth $809 \quad$ Planet. Sci. Lett. 171, 517-531.

810 Salters, V. J. M., Longhi, J. E and Bizimis, M. (2002) Near mantle solidus trace element 811 partitioning at up to $3.4 \mathrm{GPa}$, Geochem. Geophys. Geosyst., 7, Q04G17, doi: $812 \quad 10.1029 / 2001 \mathrm{GC} 000148$. 
813 Sharp, W. D., Turrin, B. D., Renne,, P. R. and Lanphere, M. A. (1996), The ${ }^{40} \mathrm{Ar} /{ }^{39} \mathrm{Ar}$ and K/Ar

814 dating of lavas from the Hilo 1-km core hole, Hawaii Scientific Drilling Project, J. Geophys. Res.,

815 101, 11,607-11,616.

816 Sharp, W. D., and P. R. Renne (2005) $\mathrm{The}{ }^{40} \mathrm{Ar} /{ }^{39} \mathrm{Ar}$ dating of core recovered by the Hawaii

817 Scientific Drilling Project (phase 2), Hilo, Hawaii, Geochem. Geophys. Geosyst., 6, Q04G17, doi:

$818 \quad 10.1029 / 2004 G C 000846$.

819 Shaw, D. M. (1970) Trace element fractionation during anatexis, Geochem. Cosmochem. Acta,

$820 \quad 34,237-243$.

821 Sobolev, A.V., Hofmann, A. W., Sobolev, S. V. and Nikogosian, I. K. (2005) An olivine free 822 mantle source of Hawaiian shield basalts. Nature 434, 590-597, 2005.

823 Staudigal, H., Zindler, A., Hart, S. R., Leslie, T., Chen, C.-Y. and Clague, D. (1984) The isotopic

824 systematics of a juvenile intraplate volcano: $\mathrm{Pb}, \mathrm{Nd}$, and $\mathrm{Sr}$ isotope ratios from Loihi seamount,

825 Hawaii, Earth Planet Sci. Lett. 69, 13-29.

826 Stolper, E. M., DePaolo, D. J. and Thomas, D. M. (1996) Introduction to special section: Hawaii

827 Scientific Drilling Project, J. Geophys. Res. 101, 11,593-11,598.

828 Stolper, E., Sherman, S., Garcia, M., Baker, M., and Seaman, C. (2004), Glass in the submarine

829 section of the HSDP2 drill core, Hilo, Hawaii, Geochem. Geophys. Geosyst., 5, Q07G15,

830 doi:10.1029/2003GC000553.

831 Stolper, E. M., DePaolo, D. J. and Thomas, D. M. (2009) Deep drilling into a mantle plume

832 volcano: The Hawaii Scientific Drilling Project, Scientific Drilling, 7, 4-14.

833 Takahashi, E., Shimazaky, T., Tsuzaki, Y. and Yoshida, H. (1992) Melting studies of a peridotite 834 KLB-1 to $6.5 \mathrm{GPa}$, and the origin of basaltic magmas, Phil. Trans. R. Soc. Lond. A 342, 105-120. 
835 Takahasi, E. and Nakajima, K. Melting Processes in the Hawaiian plume: an experimental study, 836 (2002) in Hawaiian Volcanoes: Deep Underwater perspectives, Geophys. Monogr. Ser., 128, 837 edited by E, Takahashi, P. W. Lipman, M. O. Garcia, J. Naka and S. Aramaki, pp. 403-418, AGU, 838 Washington, D. C.

839 Trusdell, F. A., and Lockwood, J. P. (in press, a) Geologic Map of the Northeast Flank of Mauna 840 Loa Volcano, Island of Hawaii, Hawaii: U.S. Geological Survey SIM 2932-A, scale 1:50,000.

841 Trusdell, F. A., and Lockwood, J. P. (in press, b) Geologic Map of the Central-Southeast Flank of 842 Mauna Loa Volcano, Island of Hawaii, Hawaii: U.S. Geological Survey SIM 2932-B, scale $843 \quad 1: 50,000$.

844 Trusdell, F. A., and Lockwood, J. P. (in press, c) Geologic Map of Southern Mauna Loa Volcano, 845 Island of Hawaii, Hawaii: U.S. Geological Survey SIM 2932-C, scale 1:50,000.

846 Wagner, T. P. and Grove T. L. (1997) Melt/harzburgite reaction in the petrogenesis of tholeiitic 847 magma from Kilauea volcano, Hawaii, Contrib. Mineral. Petrol. 131, 1-12.

848 Walter, M. J. (1998) Melting of garnet peridotite and the origin of komatiite and depleted 849 lithosphere, J. Petrol. 39, 29-60.

850 Wanless, V. D., Garcia, M. O., Rhodes, J. M., Weis, D., and M. D. Norman (2006), Shield stage 851 alkali volcanism on Mauna Loa volcano, Hawaii, J. Volcanol. Geotherm. Res.151, 141-155.

852 Watson, S. and McKenzie, D. (1991) Melt generation by plumes: A study of Hawaiian 853 volcanism, J. Petrol. 32, 501-537.

854 Weis, D., Garcia, M. O., Rhodes, J. M., Jellinek, M. and Scoates, J. S. (2011), Role of the deep 855 mantle in generating the compositional asymmetry of the Hawaiian mantle plume, Nature 856 Geoscience, 4, 831-838. 
857 Wilkinson, J. F. G. and Hensel, H. D. (1988) The petrology of some picrites from Mauna Loa and 858 Kilaue, Hawaii, Contrib. Mineral. Petrol, 98, 326-345.

859 Wright, T. L. (1971) Chemistry of Kilauea and Mauna Loa lava in space and time, US Geol. Surv. 860 Professional Paper 735, $40 \mathrm{p}$.

861 Yaxley, G. M. and Green, D. H. (1998) Reactions between eclogite and peridotite: Mantle re862 fertilization by subduction of oceanic crust, Schweiz. Mineral. Petrogr. Mitt. 78, 243-255. 
Figure 1a

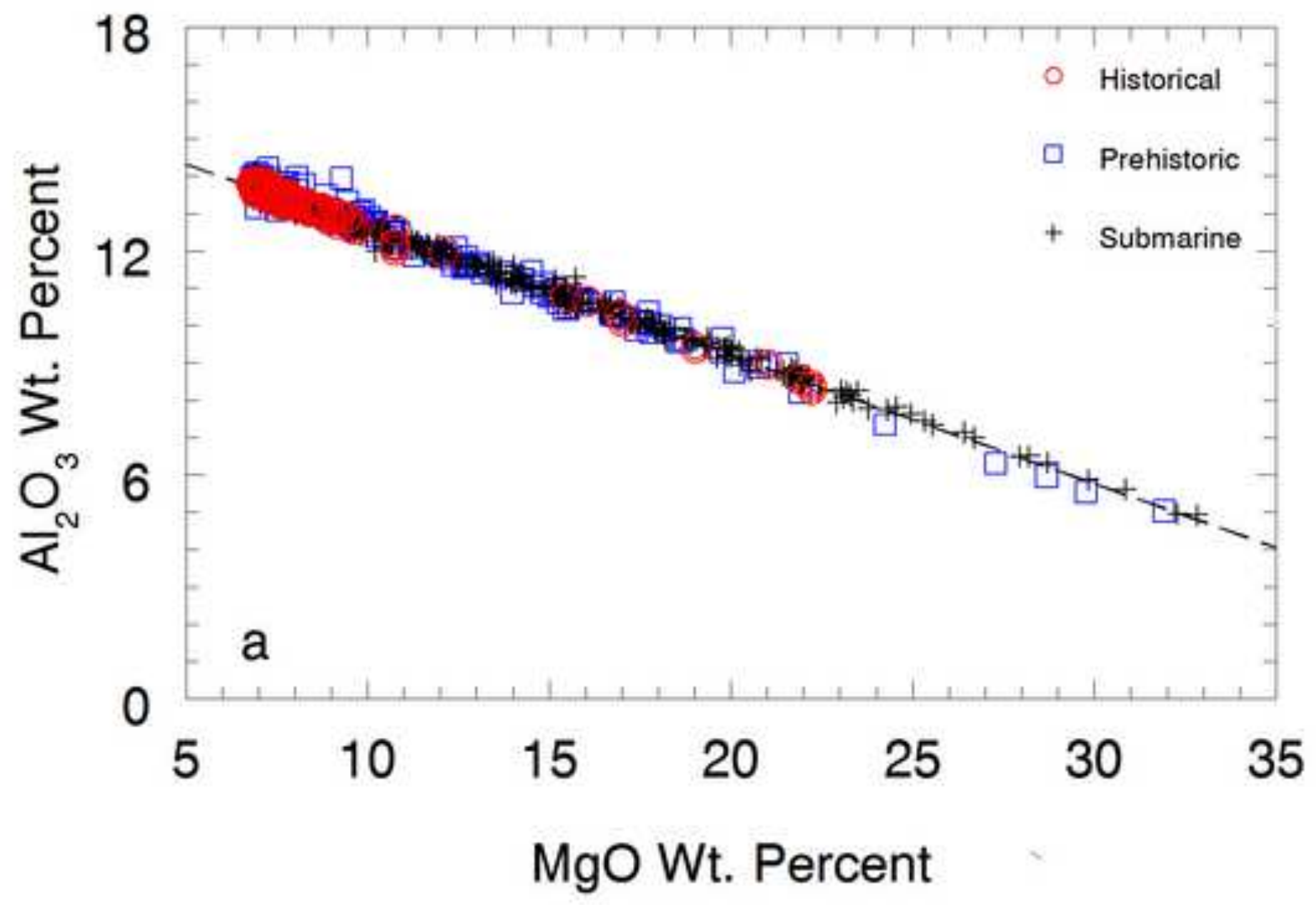


Figure 1b

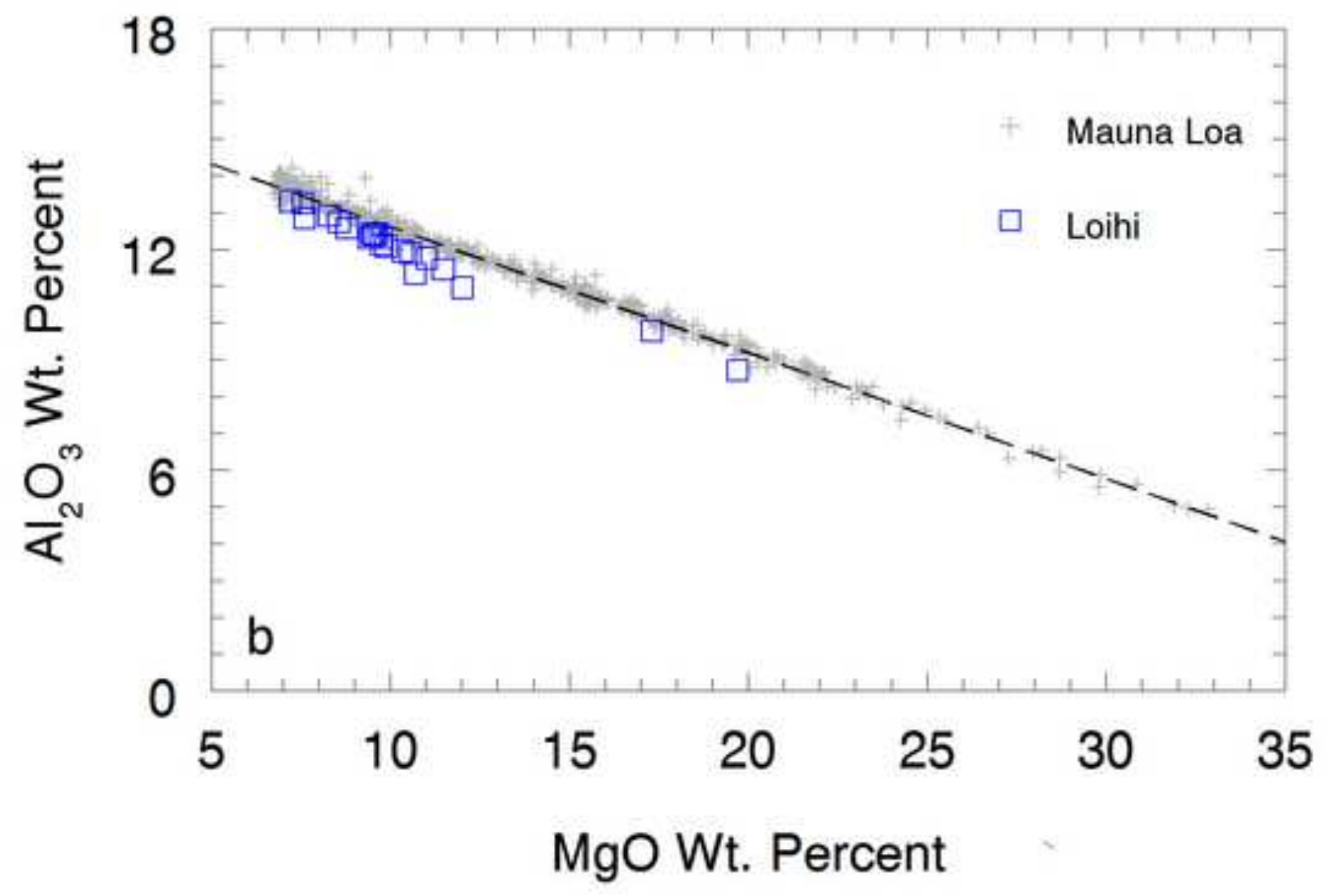


Figure 1c

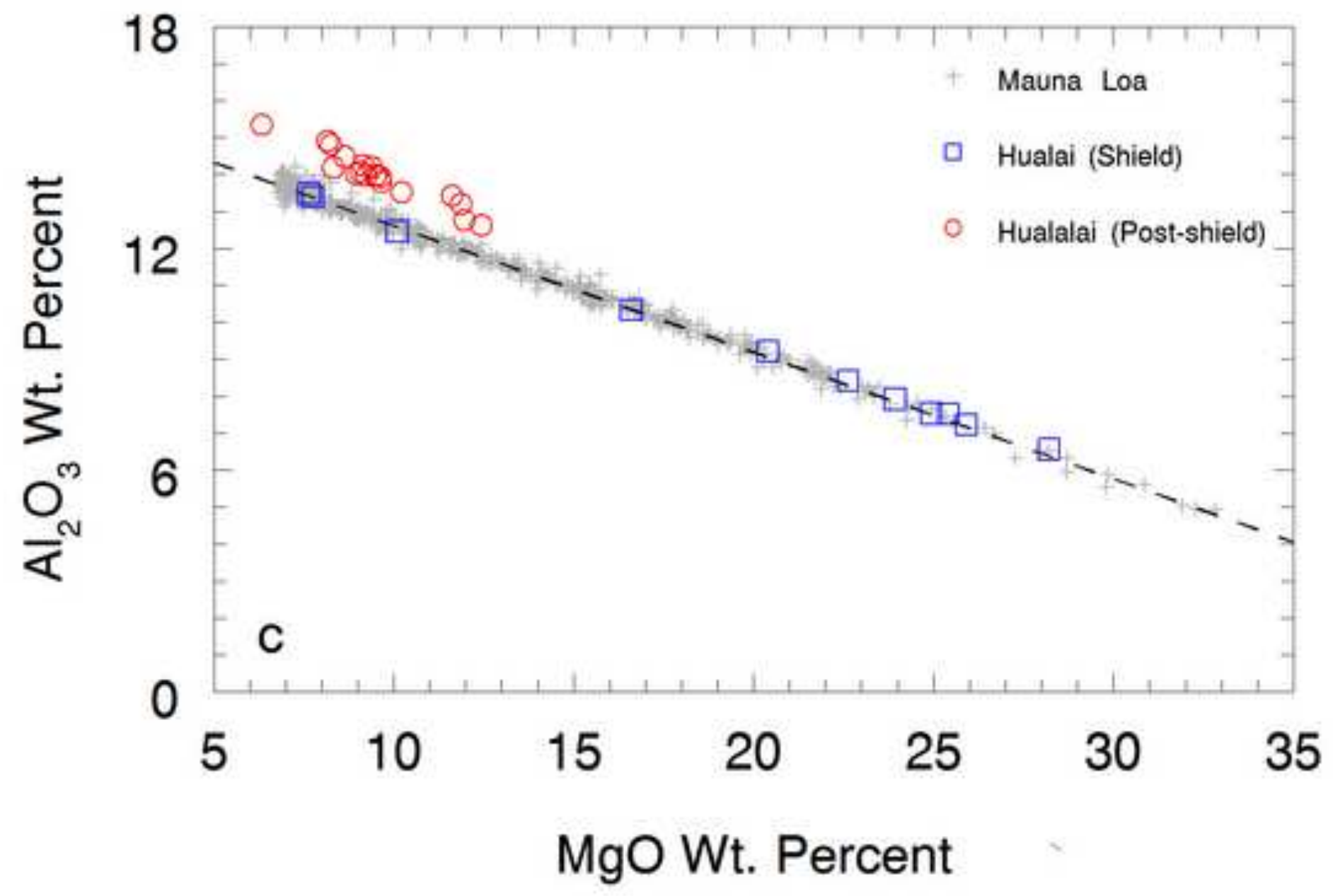


Figure 1d

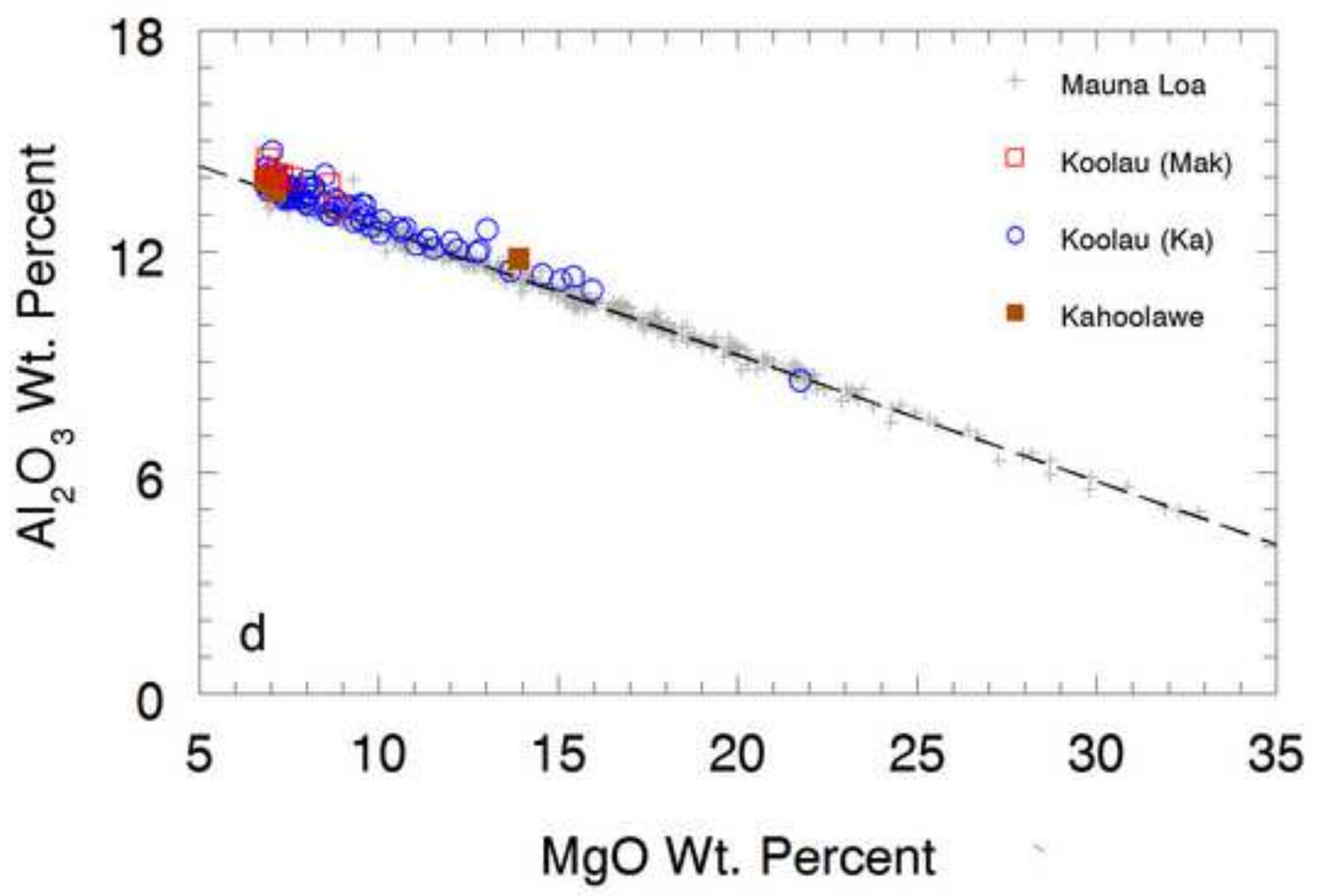


Figure 2a

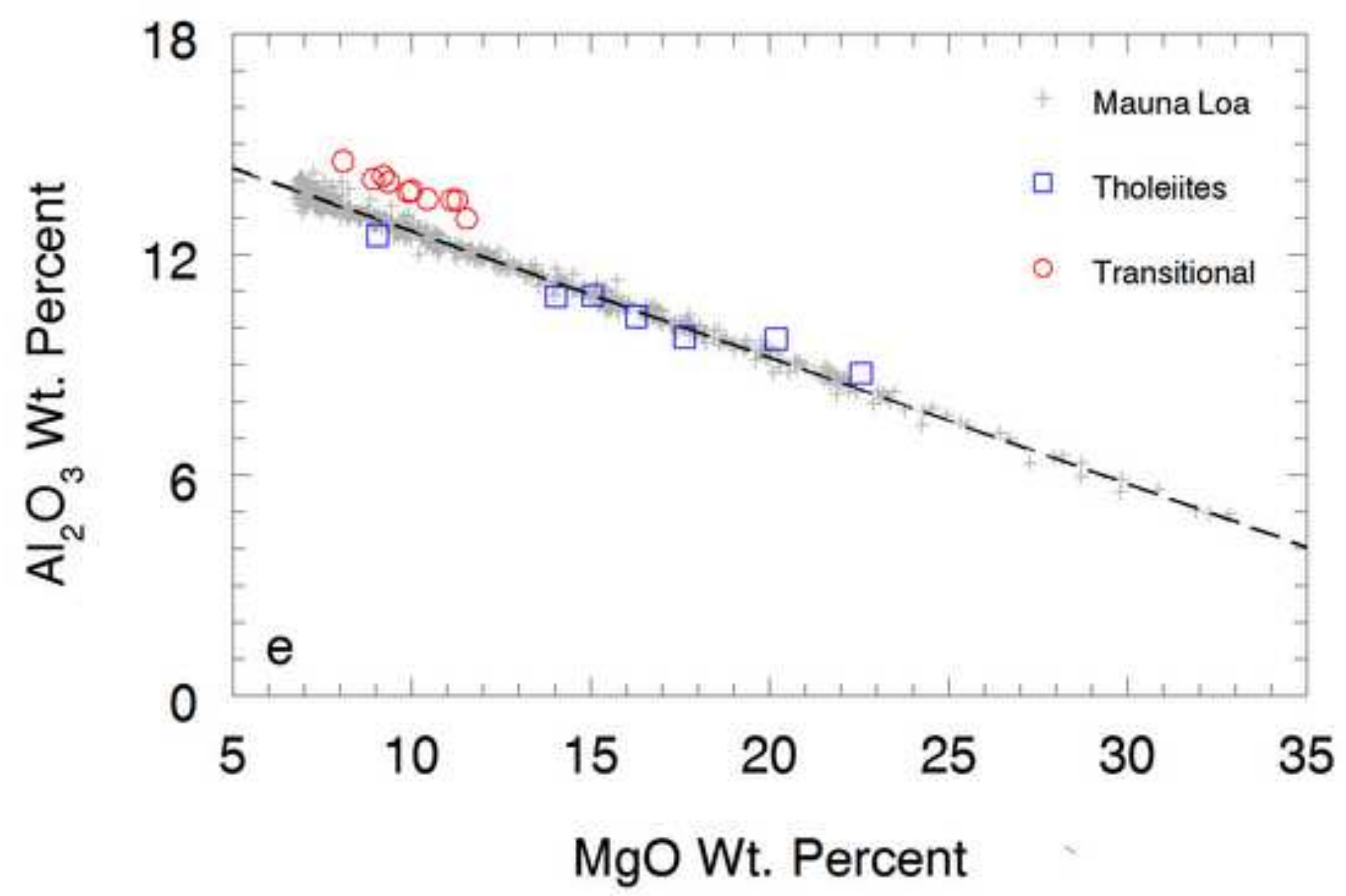


Figure $2 b$

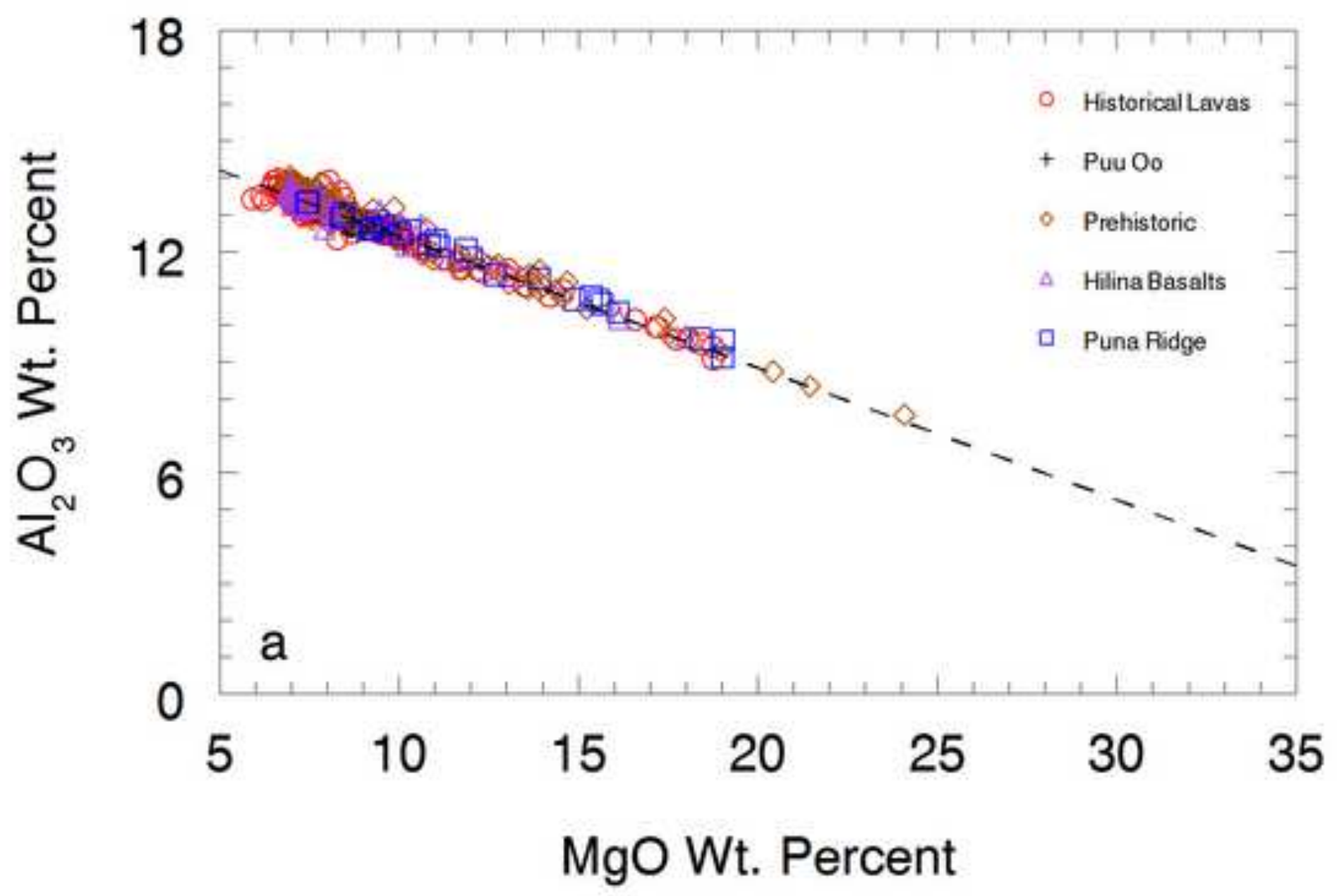


Figure 2c

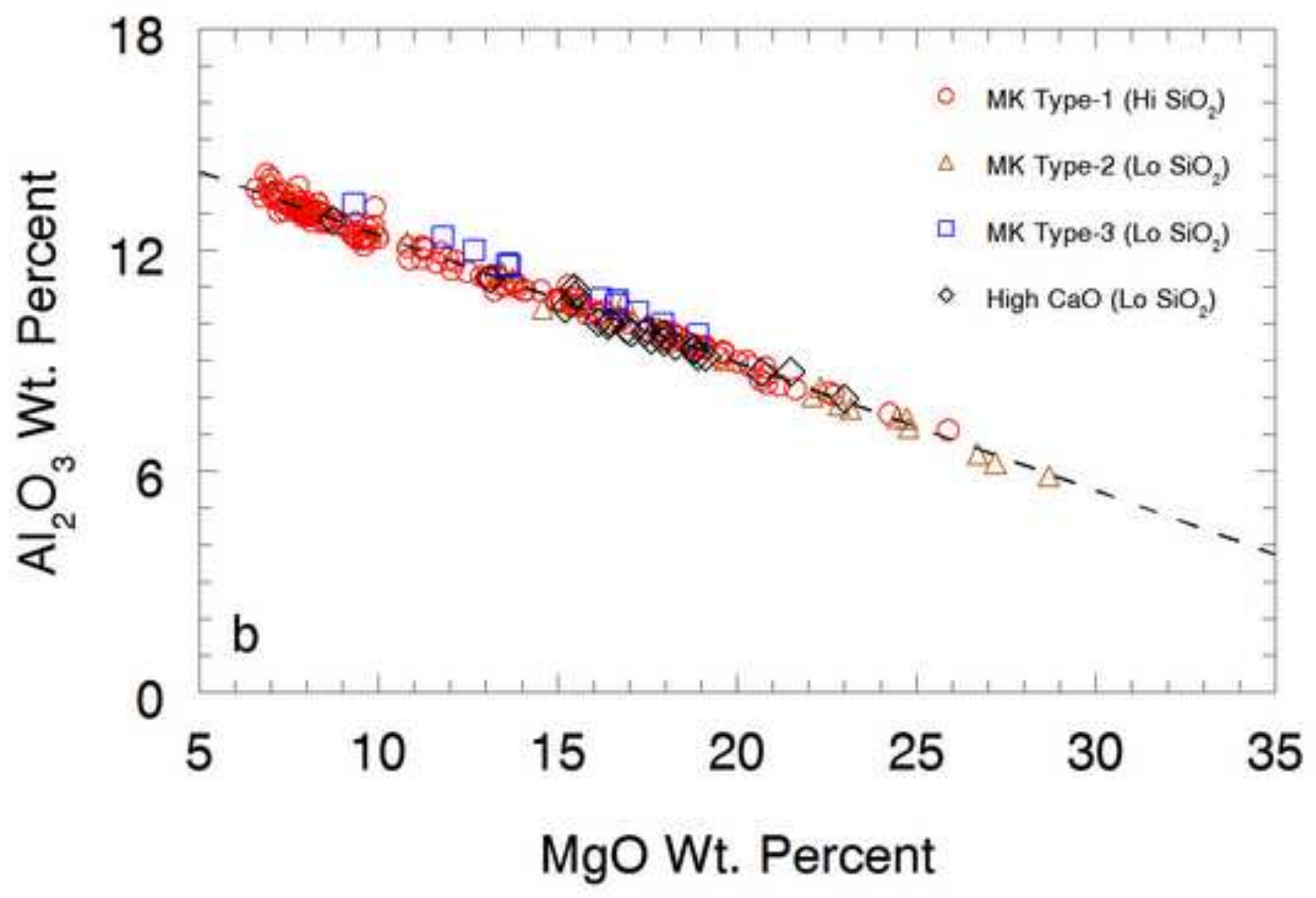


Figure 2d

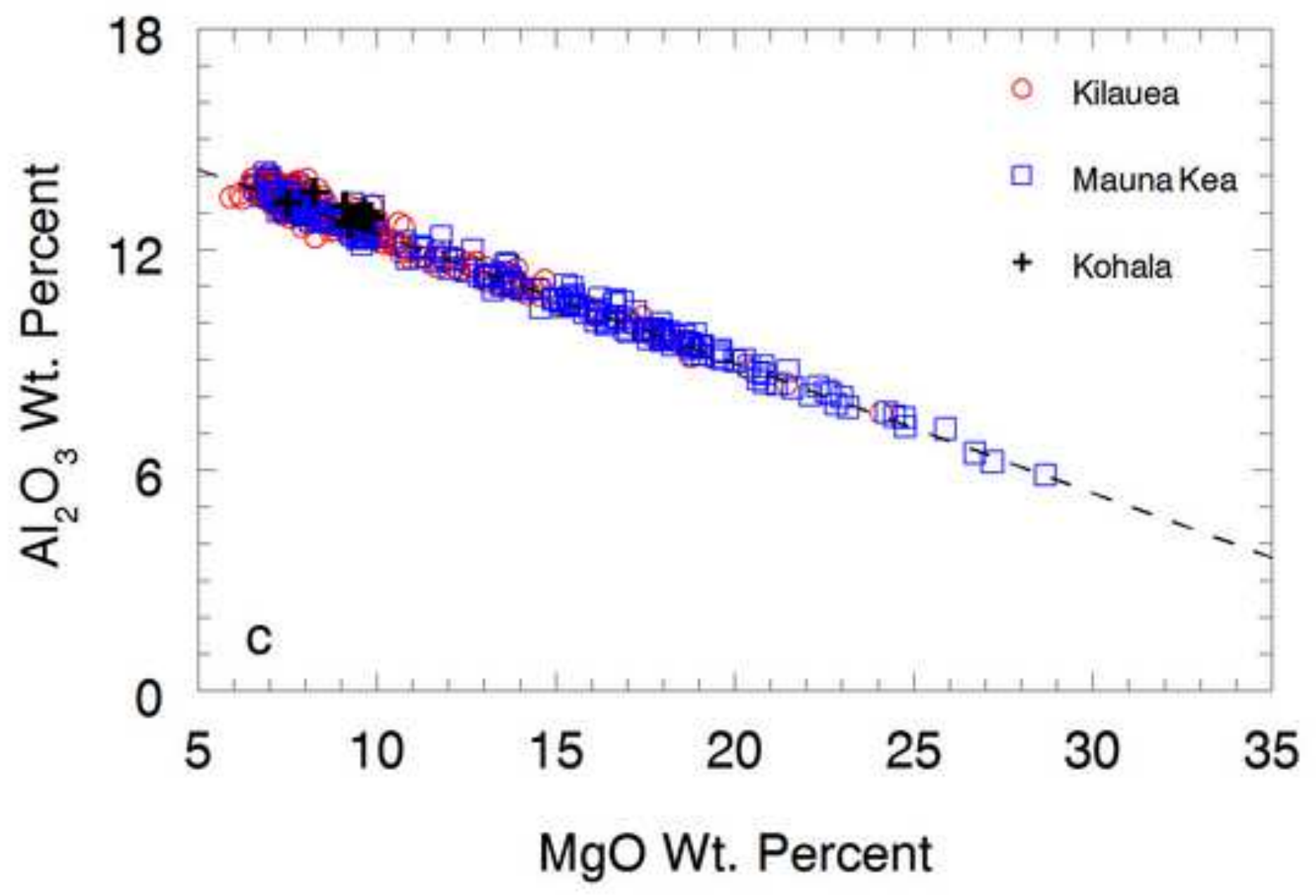


Figure 3

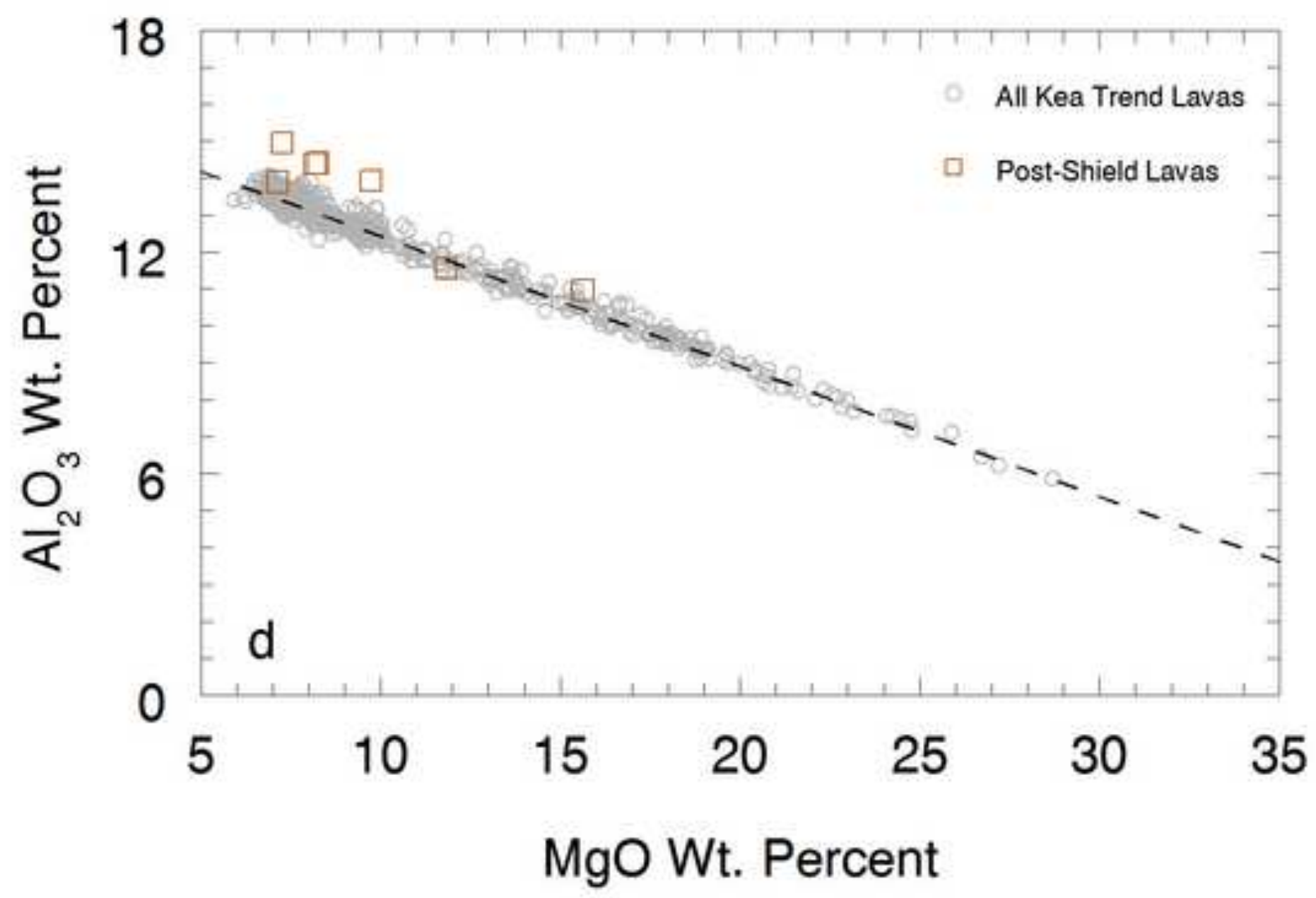


Figure 4a

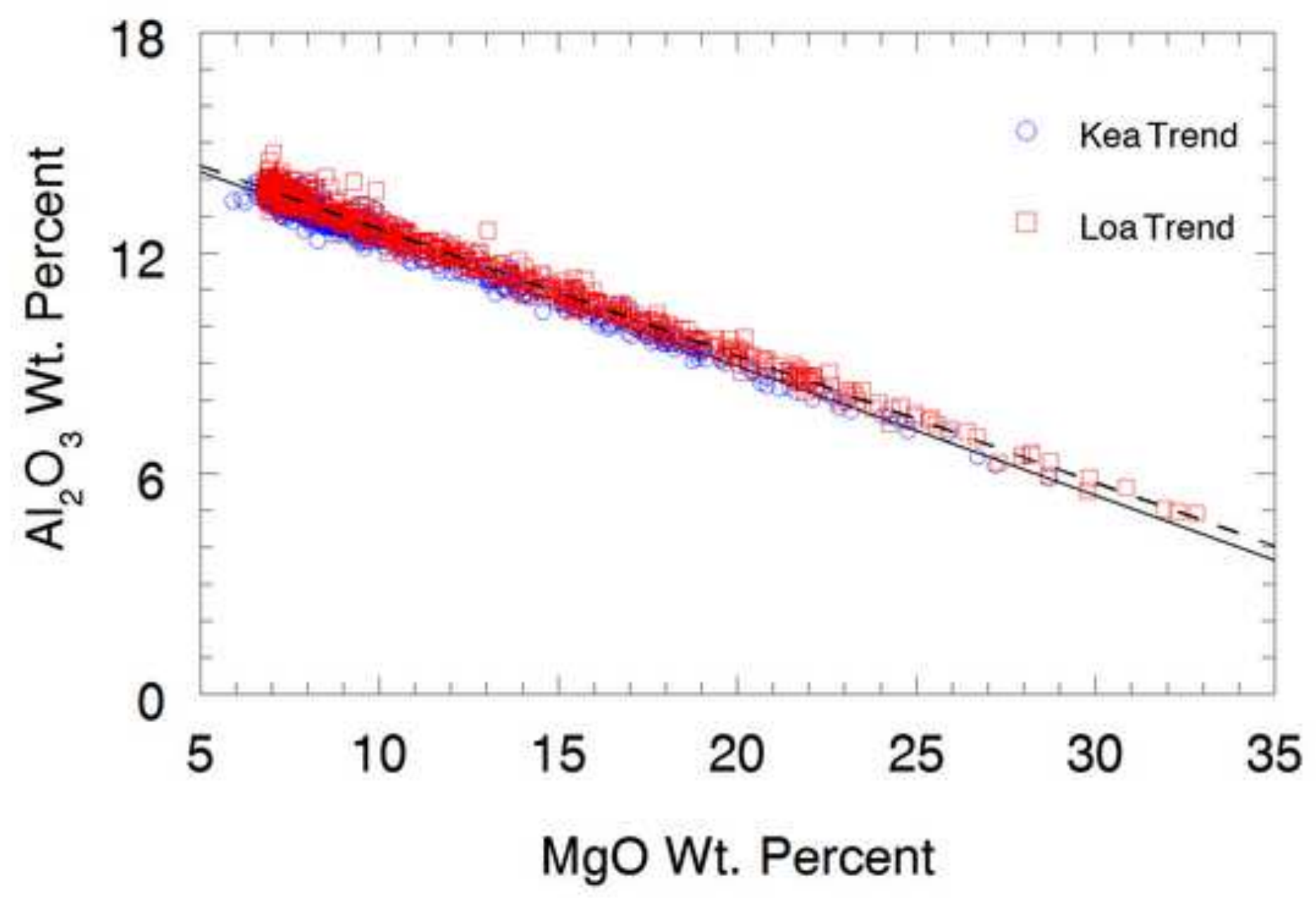




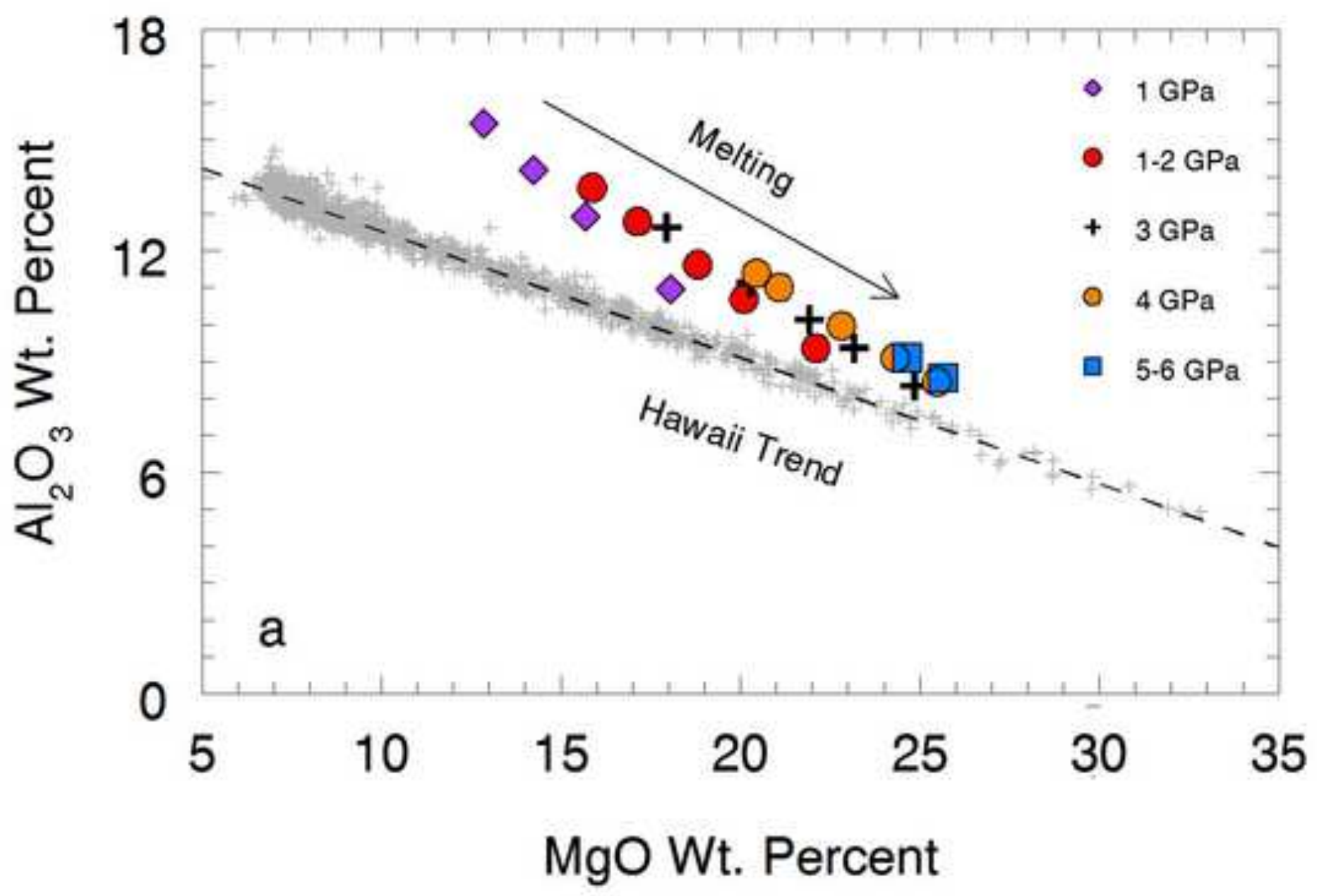




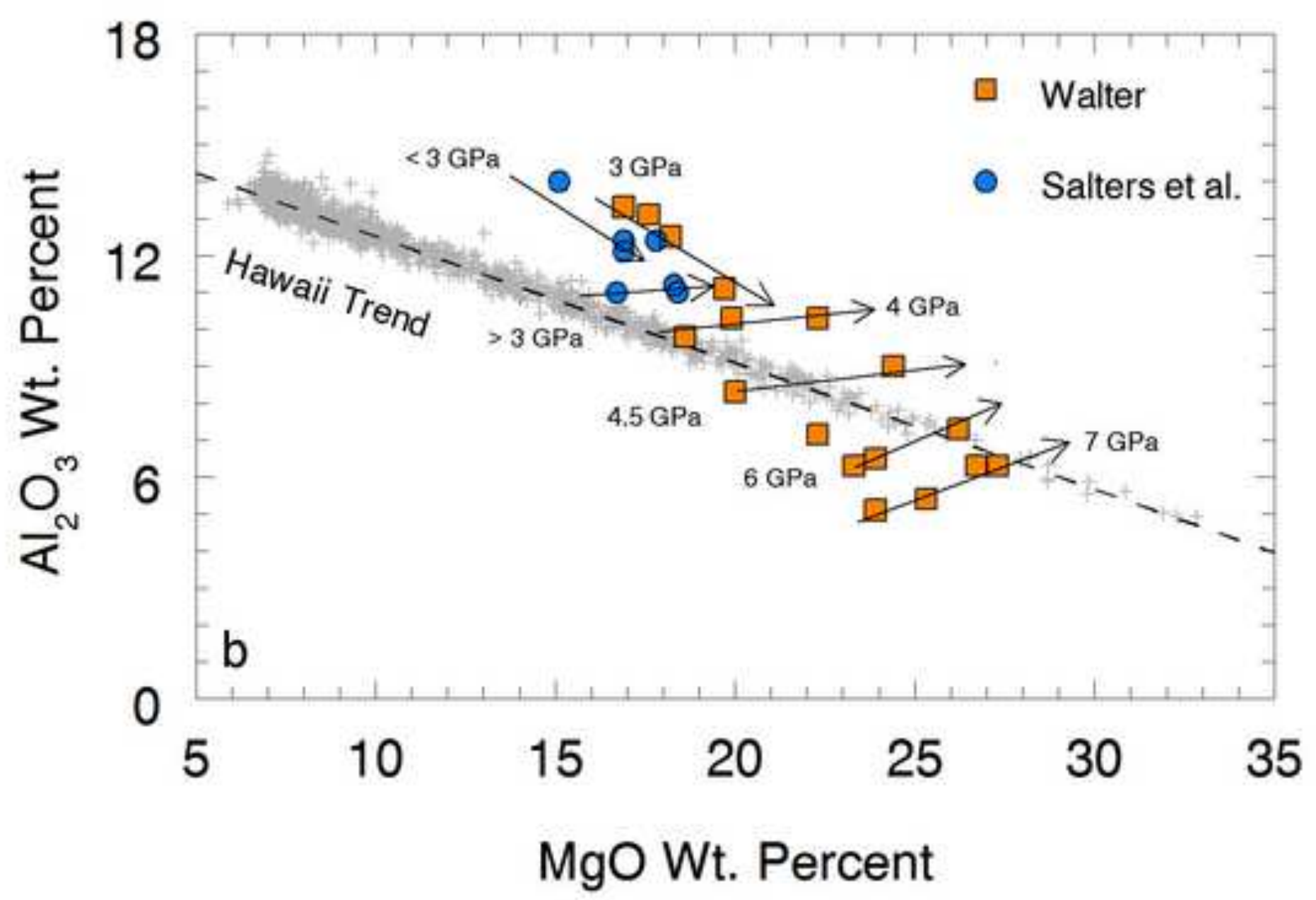




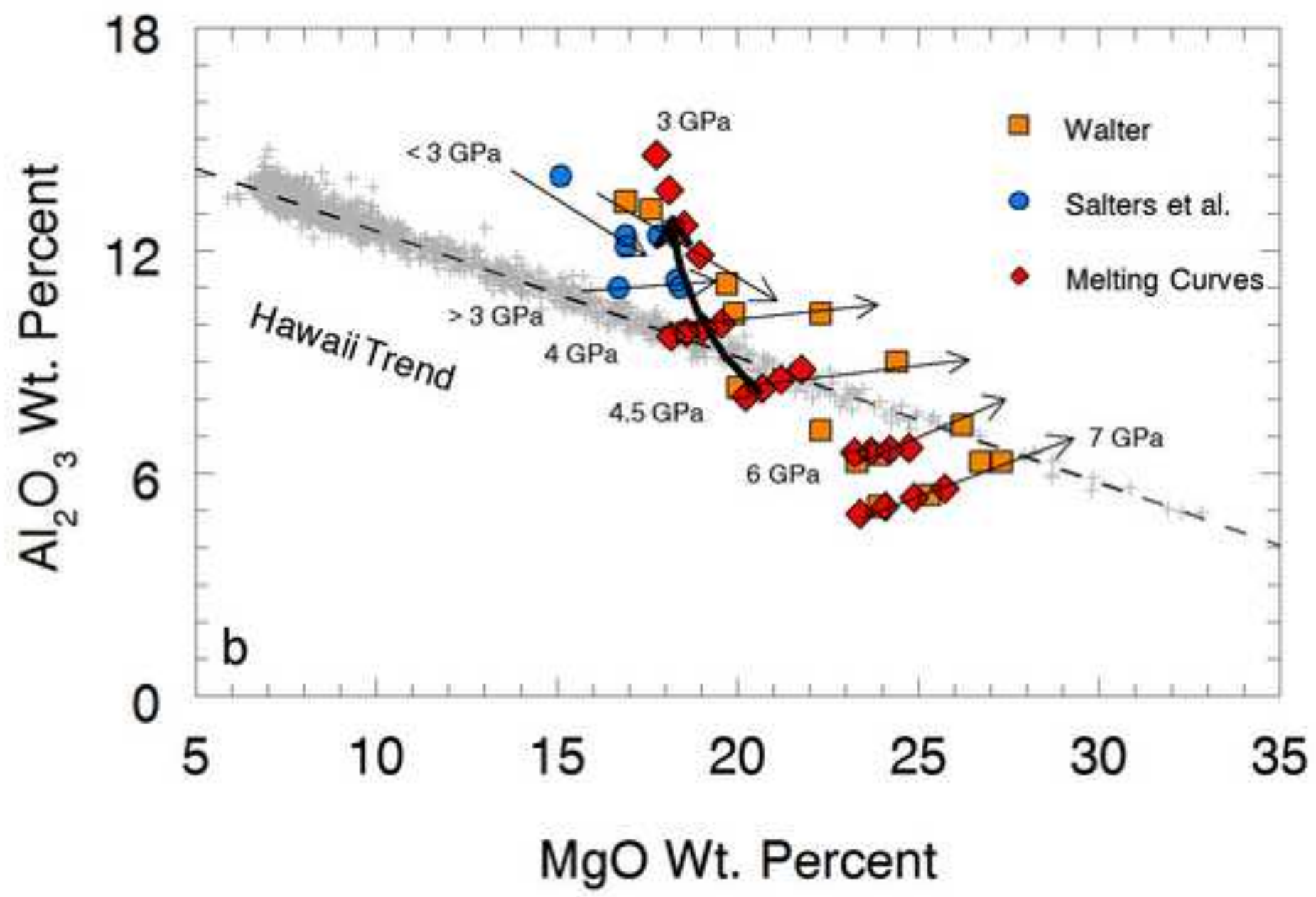




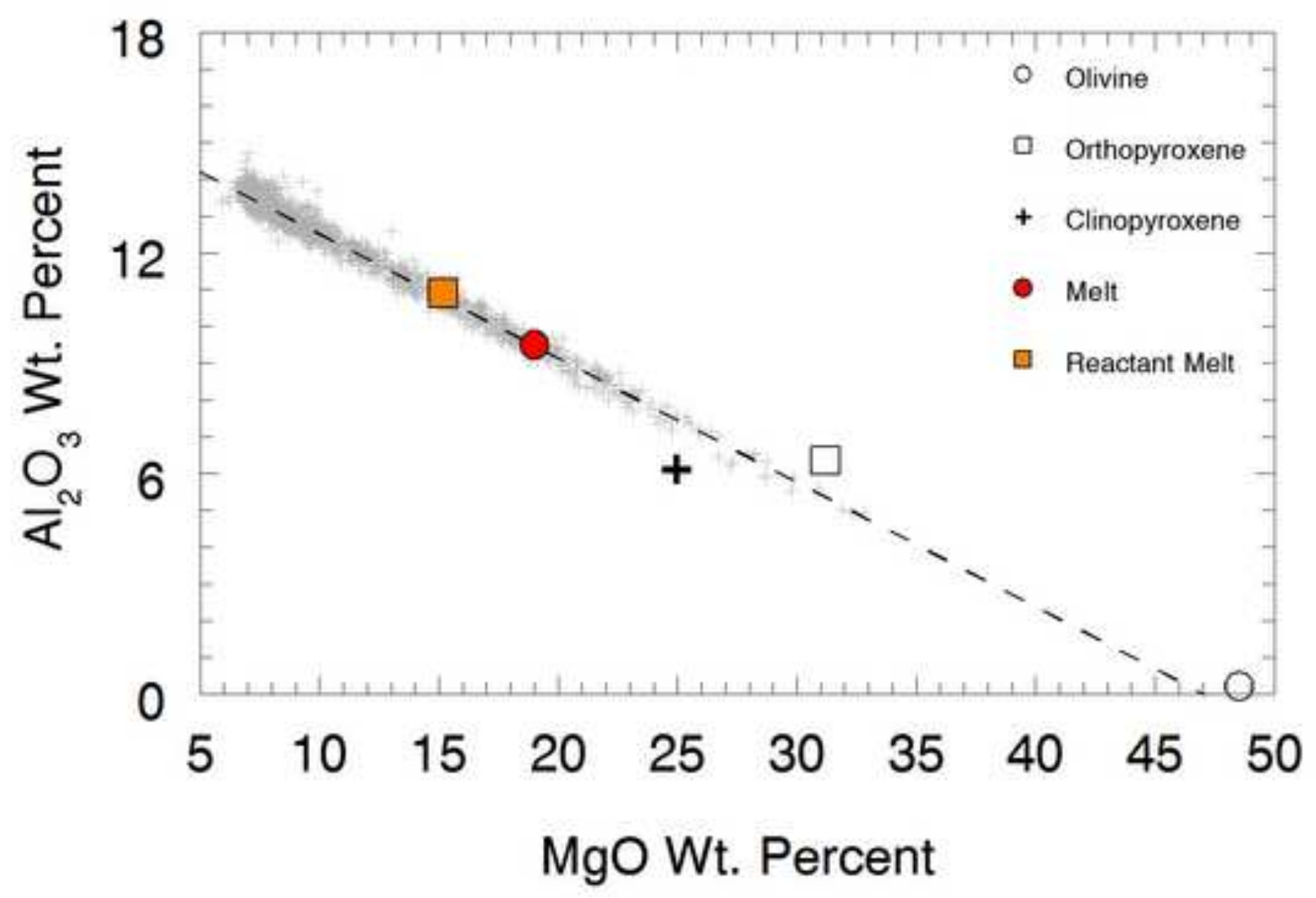

